\title{
Selecting a Green, Agile and Industry 4.0 Supplier With the Fuzzy-Swara-Bwm Integrated Method
}

Mehmet Ali Tas ( $\nabla$ mehmetali.tas@tau.edu.tr)

Turk-Alman Universitesi https://orcid.org/0000-0003-3333-7972

\section{Serap Akcan}

Toros Universitesi

\section{Research Article}

Keywords: MCDM, Fuzzy SWARA, Fuzzy BWM, Fuzzy Logic, Supplier Selection

Posted Date: November 2nd, 2021

DOl: https://doi.org/10.21203/rs.3.rs-365657/v1

License: (c) (1) This work is licensed under a Creative Commons Attribution 4.0 International License. Read Full License 


\title{
SELECTING A GREEN, AGILE AND INDUSTRY 4.0 SUPPLIER WITH THE FUZZY-SWARA-BWM INTEGRATED METHOD
}

\author{
Mehmet Ali Taş ${ }^{1}$, Serap Akcan² \\ ( ${ }^{1}$ Turkish-German University, Department of Industrial Engineering, Engineering Faculty, İstanbul, Turkey) \\ ( 1 mail: mehmetali.tas@tau.edu.tr) ( ${ }^{1}$ Corresponding Author) \\ (2Tarsus University, Department of Industrial Engineering, Engineering Faculty, Mersin, Turkey) \\ ( ${ }^{2}$ mail: serapakcan@tarsus.edu.tr)
}

\section{Abstract}

Businesses establish supply chains in order to continue their activities. Choosing the suppliers to take part in these supply chains poses many challenges in rapidly changing conditions. Environmental concerns in the public, competitive market structures, and developing technological opportunities affect the decision-making processes. Different criteria are taken into consideration instead of traditional criteria such as cost and service. In this study, green, agile, and Industry 4.0 dimensions and the criteria under these dimensions are defined. According to these, the problem of selecting the supplier that responds to the expectations of the markets and enables them to increase their competitiveness was discussed. Fuzzy SWARA and fuzzy BMW methods were applied in an integrated way to solve the supplier selection problem under these three dimensions. A real case study was also presented. In the study, the results obtained by creating different scenarios were compared and sensitivity analysis was made. The results obtained show that the hybrid method developed in this study is effective in supplier selection problems. As a result of the study, the most important evaluation dimension is "agile" and the most important criterion is "delivery speed".

Keywords: MCDM, Fuzzy SWARA, Fuzzy BWM, Fuzzy Logic, Supplier Selection.

\section{Introduction}

Although its structure is divided into various units, a business should actually be thought of as a single and interconnected organization. Organizations being able to manage all of their processes holistically will ensure that the obtained outputs are more successful. The supply chains that the businesses establish to continue operating have great importance at this point.

Supply chains express the planning, design and control of the service, product and information flow from the manufacturer to the customer and refers to the organizations including the supplier (Srivastava 2007). Since the selection of the suppliers in the supply chains will directly affect supply chain performance; it is necessary to determine the appropriate supplier. Businesses look at various criteria when selecting suppliers. These changing every day causes the supplier selection application to always have a new and current problem. Today, the purchased product/service is expected to be environmentalist in all utilization phases. The legal regulations being subjected to, pressure from factors such as manufacturers and consumers in the market, social responsibility and gaining advantage by reducing cost, have caused organizations to focus on environmental issues more seriously (Shaw et al. 2010). 
Although manufacturing technologies make mass production quite easier, customers demand products that are adapted to their personal requests and want the product/service they purchased to be unique and customized. Predicting the expectations of customers beforehand provides great outcomes in the industry the business operates in. Intuitive industry analysis predictions based on experience can cause mistakes. Businesses that can observe the requests and expectations of customers with advances methods can have competitive advantage.

The developing technology has affected people's entire lives, especially daily life. The Industry 4.0 philosophy has surfaced with the integration of technological facilities into industry. With this transformation that affected all processes, organizations are reconstructing their activities with Industry 4.0. Industry 4.0 presents great convenience for the control, management and intervention of all fields. It is clear that the Industry 4.0 philosophy and the usage of the technology it brings will be on the agenda of organizations even more.

In this study, three evaluation dimensions, "green", "agile" and "Industry 4.0" were created. A plastic product manufacturer was chosen because it operates in a sector that could be suitable for using these dimensions in supplier selection. This manufacturer will choose between four alternative suppliers. A detailed literature review has been done for the criteria in the three evaluation dimensions of supplier selection. Additionally, the opinions of the three decision makers (DM) working in the business subject to the application were consulted. A total of 21 evaluation criteria were selected as a result of the literature review and the combination of the DM opinions. Fuzzy SWARA (Step-Wise Weight Assessment Ratio Analysis), a multi-criteria decision making (MCDM) method, was chosen to determine the weights of the dimensions and criteria.

The fuzzy BWM (Best-Worst Method) was performed to evaluate alternatives. This method includes determining the best and worst alternatives and doing comparisons according to these two alternatives. This way, the DM can express the evaluation range created more accurately and be compare more consistently. After the four alternative suppliers have been evaluated alternatively, the criteria weights were changed, 21 different scenarios were created and the sensitivity of the results were checked.

Reviewing the literature, a study containing the recent fuzzy SWARA and BWM methods in an integrated way has not been encountered. These two methods used integrally, have been applied to a real life problem. Also, as seen as the result of the detailed literature review; the lack of a supplier problem using green, agile and Industry 4.0 dimensions together is another reason that makes the study unique.

This study consists of five titles. After the introduction part, studies about the topic in the literature are shown in the second title. In the third title, there is the methodology part involving the evaluation dimensions used in the application, MCDM and fuzzy logic. The fourth title consists of the application topic, determining the criteria and alternatives, and the application. In the final title, there is the study results and conclusions as a result of the application.

\section{Literature review}


Supplier selection problems using multi-criteria decision making methods related to green, agile and Industry 4.0, which constitute the scope of the research, have been investigated.

\subsection{Green supplier selection}

The concept of green supply chains can be summarized as an environmental reflection of the classical supply chain definition in its most general form. The topic of environment occupies an important place among the issues discussed by society and organizations (Kannan et al. 2015). Regardless of the sector, all businesses have duties and responsibilities to restore the ecological balance. When creating supply chains, it is necessary to organize the processes and activities that the business creates and the process and activities it is in, according to the determined green goals. In each moment of the implementation of the decisions taken in this direction, the environment should be given importance, green should be taken into consideration (Akcan and Taş 2019). In this way, the created supply chains should also be "green supply chains" (Zhu et al. 2008). Green supply chain management is also defined as a management strategy that takes the environmental effects and efficiency of resource usage in supply chains into account and aims to minimize the negative effects on the environment (Green et al. 2012). The activities changes between supply chain management and green supply chain management are shown Table 1.

Table 1. Changes between the supply chain management and green supply chain management

\begin{tabular}{|c|c|c|l|}
\hline Activity & $\begin{array}{c}\text { Supply chain } \\
\text { management }\end{array}$ & $\begin{array}{c}\text { Green supply } \\
\text { chain } \\
\text { management }\end{array}$ & \multicolumn{1}{|c|}{ Changes } \\
\hline 1 & Manufacturing & $\begin{array}{c}\text { Green } \\
\text { manufacturing }\end{array}$ & $\begin{array}{l}\text { When manufacturing, having the ability to do } \\
\text { manufacturing without harming the } \\
\text { environment instead of doing only quality, } \\
\text { flexible and cheap manufacturing. }\end{array}$ \\
\hline 2 & Purchasing & Green & $\begin{array}{l}\text { Prioritizing purchasing environment-friendly } \\
\text { products, materials and services with low } \\
\text { resource consumption. }\end{array}$ \\
\hline 3 & Packaging & $\begin{array}{l}\text { Green } \\
\text { packaging }\end{array}$ & $\begin{array}{l}\text { Using recyclable materials when doing } \\
\text { packaging. }\end{array}$ \\
\hline 5 & Listribution & $\begin{array}{c}\text { Reverse } \\
\text { logistics }\end{array}$ & $\begin{array}{l}\text { Greating a logistics structure including } \\
\text { reusing, recycling, recovering value activities. }\end{array}$ \\
\hline & distribution & $\begin{array}{l}\text { Creating a distribution network that } \\
\text { consumes low CO }{ }_{2} \text { producing, environment- } \\
\text { friendly energy during the distribution of a } \\
\text { service or product produced. }\end{array}$ \\
\hline
\end{tabular}

Kuo et al. (2015), focused on a green supplier selection of an electronic company that complies to the standards. DANP, the combination of ANP (Analytic Network Process) and DEMATEL (Decision Making Trial and Evaluation Laboratory) was used in the study for the criteria weights, VIKOR (Vlse Criteriaijumska Optimizacija Kompromisno Resenje) was used to evaluate the alternative green suppliers. Hashemi et al. (2015) performed ANP to find the criteria weights and advanced GRA (Gray Relational Analysis) for alternative selection in the green supplier selection 
of an Iranian automobile manufacturer. Sivaprakasam et al. (2015) used AHP (Analytic Hierarchy Process) to evaluate criteria and alternatives in the green supplier selection of a textile manufacturing business. Freeman and Chen (2015) weighted subjective criteria with AHP and objective criteria with Entropy in the green supplier selection of a Chinese electronic machine manufacturer and made alternative selection with TOPSIS (Technique for Order Preference by Similarity to an Ideal Solution). Keshavarz Ghorabaee et al. (2016) used interval type-2 fuzzy numbers in a green supplier selection study, in which the criteria weights were made with Entropy and the alternative ordering was made with WASPAS (Weighted Aggregated Sum Product Assessment). Wang Chen et al. (2016) made a green supplier selection for an optical prism manufacturer in Taiwan. In the study using triangular fuzzy numbers, the weights of the criteria were found with fuzzy AHP, the alternative weights were found with fuzzy TOPSIS. Yazdani et al. (2017) made a green supplier selection for the purchasing and logistics unit of a dairy company in Iran. In the study where the criteria weights were determined by QFD (Quality Function Deployment) and DEMATEL, the alternative evaluation was done with the COPRAS (Complex Proportional Assessment) method. Guo et al. (2017) used FAD (Fuzzy Axiomatic Design) to evaluate green supplier alternatives for a clothing manufacturer in Hong Kong and for the best green supplier selection application. Mousakhani et al. (2017) found the criteria weights with extended interval type-2 fuzzy TOPSIS in the green supplier selection of an automobile battery manufacturer in Iran, and found the alternative ordering with the interval type-2 fuzzy Hamming distance measure. Quan et al. (2018) as a group decision, made the selection of the best timber green supplier for a real estate company in China. LINMAP (Linear Programming Technique for Multidimensional Analysis of Preference) was used for the criteria weights, MULTIMOORA (MultiObjective Optimization on the Basis of Ratio Analysis plus Full Multiplicative Form) was used to evaluate green suppliers. Banaeian et al. (2018) compared the results using fuzzy TOPSIS, fuzzy VIKOR and fuzzy GRA using triangular fuzzy numbers in the green supplier selection application of the agricultural food manufacturer for cooking oil. Gupta et al. (2019) made a green supplier selection application for an automobile company in India. Fuzzy AHP was used for criteria weights, fuzzy TOPSIS, fuzzy WASPAS and fuzzy MABAC (Multi Attributive Border Approximation Area Comparison) were used for alternative ordering, and the results were compared. Jayant and Agarwal (2019) employed DEMATEL to determine the relationship between the criteria, AHP for criteria weights and TOPSIS for alternative ordering in a green supplier selection application of an electronics sector company in India. Lu et al. (2019) made a green supplier selection for a business in the straw biomass industry in China. The criteria, cloud model were evaluated with the fuzzy AHP, and the alternative green suppliers were evaluated with the model established with the probability degree.

\subsection{Agile supplier selection}

Before defining the agile supply chain, the concept "agile" must be defined. According to Christopher (2000), agility is to increase the ability to meet demands by showing flexibility and rapid adaptation to suddenly shifting demands in manufacturing. Mangan and Lalwani (2016) defined agility as "coping with demand fluctuations". The concept has started to be discussed in large scales with the expansion of this flexibility ability shown in manufacturing to the entirety of organizations, and the flexibility of all work flows and organizational activities. In fact, since the concept of agility emerges from a flexible manufacturing system, its main starting point can be considered as flexibility. The emergence of agility is related to the flexibility ability (Abdelilah et al. 2018). It can be also defined as adapting by moving quickly, thus creating environments that 
have the chance to be sustainable, continuously aim for development, evaluate opportunities (Ulrich and Yeung, 2019).

Integrated structures and uninterrupted processes can be obtained with the spread of agility to the entirety of the organization. The activities within the business of the supply chains businesses create such as manufacturing, customer relationships, sales etc. are expected to be agile (Prater et al. 2001). The concept of an agile supply chain emerged with the integration of agility with supply chains. By means of agile supply chains and agile activities, it is possible to provide products and services customized for the customers and differentiated from the standard (Bottani, 2010). Activities that increase customer satisfaction can be conducted by monitoring customer demands in order to adapt to the rapid changes in agile supply chains (Alimardani et al. 2013). In agile supply chains, the interaction between suppliers should be flexible and should be sensitive to every type of change (Gunasekaran 1999). The selection of the mentioned suppliers is made for the compatible cooperation to be established. Although the agile criteria by which the supplier will be evaluated according to the products, raw material and services to be procured may differ slightly, businesses should have specific strategies suitable for the purposes of agile supplier selection (Beikkhakhian et al. 2015; Luo et al. 2009).

When past studies are examined, Zhou et al. (2008) used AHP and FCE (Fuzzy Comprehensive Evaluation) for the supplier selection in the agile supply chain for a machine tool manufacturer in China. Büyüközkan and Arsenyan (2009) made the supplier selection to be in the agile supply chain of an apparel company in Turkey. The triangular fuzzy numbers and fuzzy TOPSIS method was used for finding criteria weights, and the FAD method was used for the ordering of the agile suppliers. In the study, the most important criteria according to the weight of the criteria determined by fuzzy TOPSIS were the flexibility that the supplier can show in the amount of delivery, the agility in the information systems and private business structuring. Luo et al. (2009) performed an application for the electrical appliance and equipment manufacturing industry in China. The agile suppliers to take place in the agile supply chain of the industry were examined. GA (Genetic Algorithm) and ANN (Artificial Neural Networks) were used in the study. Wu and Barnes (2009) conducted the supplier selection model for the agile supply chain with a four-phase conceptual model using ANP and multi-purpose integer linear programming. Wu et al. (2009) examined the criteria priorities with ANP, the selection model of suppliers that will be working together in the agile supply chain and other business partners using MIMOP. Dotoli et al. (2015) touched on the determination of supplier selection and order quantities and made a selection from eight alternative suppliers for a small and medium size business hydraulic power plant manufacturer in Italy. Abdollahi et al. (2015) used agile and plain criteria together on the basis of organization and product. DEMATEL, ANP and DEA (Data Envelopment Analysis) were used to calculate the relationship between criteria, to find the criteria weights and ordering alternative supplies according to plain and agile criteria, respectively. 22 evaluation criteria consisting of two dimensions named plain and agile were used in the assessment of alternative suppliers in the plain and agile evaluation portfolio and performance improvements. Lee et al. (2015) made the selection of suppliers that have the best and most high quality operations according to the Pareto efficiency. An agile supplier selection was made considering the whip effect and the size of the inventory costs. One of the four criteria groups consist of agile criteria. In the study that used a total of 25 criteria, seven of which were agile, and fuzzy TOPSIS and fuzzy AHP were used for criteria weights and alternative supplier selection, two ordering strategies were examined and the results were compared. Beikkhakhian et al. (2015) evaluated the criteria in the evaluation of 
agile supplier with the ISM method. Criteria weights were found with fuzzy AHP, alternative ordering was conducted with the fuzzy TOPSIS using triangular fuzzy numbers. In the study evaluating seven alternative agile suppliers, the most important criteria were found as, delivery speed, cost minimization and price, in order. Galankashi et al. (2016) applied triangular fuzzy numbers and fuzzy AHP (FAHP) for agile supplier selection. 12 sub-criteria under the four main criteria were used in the evaluation of the four agile suppliers. Matawale et al. (2016) made the supplier selection of the suppliers to take place in the agile supply chain of a business in the Indian automobile industry. The four main criteria and 11 sub-criteria were examined and fuzzy multilevel MCDM, fuzzy MOORA (Multi-Objective Optimization by Ratio Analysis) and fuzzy TOPSIS were used to evaluate agile suppliers. Sahu et al. (2016) conducted study evaluating the suppliers/partners taking place in the agile supply chain within the scope of comparison. In the study that transformed subjective evaluation data with fuzzy-based calculation module, the most suitable supplier/partner was selected using triangular interval value fuzzy numbers and TOPSIS. Four alternatives were evaluated with the seven main criteria and the 27 criteria under these criteria. The authors argued that the methods were efficient according to the results. Shariari and Pilevari (2016) conducted an agile supplier selection application for a cosmetic manufacturer. DEA was used to determine the efficiency of the suppliers. Better suppliers were selected as the alternatives to be evaluated and the Delphi method was chosen as the nine criteria evaluation measures. They have applied fuzzy VIKOR with trapezoidal fuzzy number data type. El Mokadem (2017) determined the criteria used in supplier selections with PCA (Principal Component Factor) analysis and surveys. They classified criteria as agility, plain and common selection criteria. The agility evaluation measures in the study were found as; flexibility, technology, service, research and development and manufacturing capacity. Dursun (2017) used fuzzy integral in the agile supplier selection problem of a hospital and evaluated the four agile suppliers in light of the criteria. Kumar et al. (2019) examined the performance criteria used in agile supplier selection. The 14 evaluation criteria determined by fuzzy DEMATEL using triangular fuzzy numbers were suggested as criteria that could be used in agile supplier selection.

\subsection{Industry 4.0 dimension}

The concept of Industry 4.0 has been defined in various ways. Kamble et al. (2018) defined it as the paradigm of information communication and continuous interaction by different physical devices using embedded electronics and technologies such as sensors connecting to a network or the internet. Communication and information exchange is no longer just between humans or between humans and machines, it can also occur among machines (M2M) (Roblek et al. 2016). Lu (2017) defines it as "an integrated, adapted, optimized, service focused and interoperable manufacturing process related to algorithms, big data and high technologies", Hermann et al. (2016) defines it as the transition paradigm towards manufacturing processes that have communication between machines and resources and no central control. The concept of Industry 4.0 is a strategic transformation move that paves the way for the creation of "smart" environments all over the world with developing technological advancements (Weyer et al. 2015). Many fields including the workforce, society, the ecology, economy, information security etc. have also been affected by the changes this transformation has done in the industry, leading to the emergence of concepts such as logistics 4.0, education 4.0, healthcare 4.0, society 4.0 and the revision of all structures (Bongomin et al. 2020). 
Technologies that triggered Industry 4.0 and are associated with Industry 4.0 can be compiled as; Internet of things (IoT), simulation, big data and analytics, augmented reality, additive manufacturing, horizontal and vertical system integration, cloud, autonomous robots, cybersecurity (Rüßmann et al. 2015). Another fruit of the process that has led to the emergence of changing paradigms such as health 4.0 and education 4.0 is the concept of supply chain 4.0. Supply chains have been digitalized and current technologies were included into their processes. The concept, which can also be referred to as the digital supply chain, can be expressed as innovative supply chain management, which is achieved by packaging, labelling, distribution and all other supply chain elements by taking advantage of the power of information technologies. Supply chain processes using Industry 4.0 technologies not only increase well known evaluation measures such as delivery speed, quality of service etc , but also increases business performances in dimensions such as environmental, social and societal (Dossou and Nachidi 2017). Selection of suppliers suitable for the Industry 4.0 era ensures the development of an effective relationship; this situation increases supply chain performance (Sachdeva et al. 2019). It is very important that suppliers support the Industry 4.0 transformation not only in their own internal processes, but also in the integration with all businesses and organizations in the supply chain.

Studies on this subject in the literature have been examined. Büyüközkan and Göçer (2018) conducted the digital supplier selection application of a business operating in airport operations in Turkey with interval value intuitive fuzzy numbers using AHP and ARAS methods. Sachdeva et al. (2019) proposed an integrated method for supplier selection that could compete with the Industry 4.0 era for an automobile manufacturer in India. In a study using intuitive fuzzy clusters, intuitive fuzzy weighted approach operator was used for DM opinions, Entropy was applied for criteria weights, TOPSIS was applied for alternative supplier selection. One of the five criteria used to evaluate the four suppliers was the efficiency of Industry 4.0 technologies. Also, the results were compared using fuzzy clusters and intuitive fuzzy clusters, where the weights were determined with Entropy. Özkaya et al. (2019) evaluated the criteria for the transition of businesses in the manufacturing sector in Turkey to Industry 4.0. ANP was used for the 4 main criteria and 26 criteria in the study, the most important criteria were found as; coordination and cooperation problem, lack of infrastructure and internet-based networks and digital culture insufficiency, respectively. Torkayesh et al. (2020) made the digital supplier selection application of the online retail store in Iran using BWM and WASPAS methods. WASPAS was employed to rank alternative digital suppliers, while BWM to add weight to seven criteria. Özbek and Ylldız (2020) implemented the digital supplier selection application in the digital supply chains created as a result of the Industry 4.0 transformation. Three digital suppliers were evaluated with the five main criteria and 20 sub-criteria for a business in the apparel sector in Turkey. Interval type-2 fuzzy numbers were used in the TOPSIS method, and sensitivity analysis was performed in 11 scenarios by changing the criteria weights. Sharma and Joshi (2020) used SWARA and WASPAS methods in digital supplier selection for the manufacturing industry. Hasan et al. (2020), in their study on flexible supplier selection in logistics 4.0; used ambiguous data transformed into triangular fuzzy numbers and used the fuzzy TOPSIS method in alternative ordering. Also, multiple choice goal programming was used to determine the order quantity. The assessment criteria, separated as quantitative and qualitative, consist of three main criteria and 19 subcriteria. In the evaluation of the five suppliers, criteria that highlight Industry 4.0 abilities such as cyber security risk management and digitalization take place alongside traditional criteria such as flexibility criteria and cost. 


\subsection{Studies on fuzzy SWARA, fuzzy BMW methods}

Studies using Fuzzy SWARA are mostly found in recent years. Mavi et al. (2017) used the fuzzy SWARA method to weight the criteria in the selection of sustainable third-party reverse logistics provider for the plastic industry. Four main criteria, economic, environmental, social and risk and 23 criteria under these criteria were considered, and 9 alternative providers were ranked with fuzzy MOORA. Similarly, Zarbakhshnia et al. (2018) focused on the evaluation of sustainable third party reverse logistics provider alternatives for an example from the automobile industry in Iran. Fuzzy SWARA was used for the weights of the criteria, and fuzzy COPRAS was used to evaluate alternatives. Perçin (2019) conducted an outsourcing provider selection to carry out the purchasing, manufacturing, planning and information systems processes of a business in the chemistry industry in Turkey. In the study where the evaluation criteria were determined by fuzzy SWARA, the alternative selection was made with FAD. Ighravwe and Oke (2019) employed fuzzy SWARA to find the weights of maintenance activities and fuzzy CORPAS to rank the factors in a study where the selection factors of maintenance technicians in the cement manufacturing plant were evaluated. Ren et al. (2019) found the criteria weights with fuzzy SWARA and alternative ranking with WASPAS in a location selection for electric vehicles in China.

The studies that apply fuzzy BWM were examined. In their two applications, Guo and Zhao (2017) used fuzzy BWM to evaluate the criteria to be considered to choose between the shipping types of products and to be bought. Amoozad Mahdiraji et al. (2018) used fuzzy BWM and COPRAS in a study examining the sustainable architecture of Iran. Omrani et al. (2018) used Taguchi, fuzzy BWM and TOPSIS in determining the most suitable combination of alternatives for energy manufacturing in Iran. Tian et al. (2018) selected the FMEA, entropy, fuzzy BWM and fuzzy VIKOR methods together in a study evaluating malfunction modes of CNC machines. Ghoushchi et al. ( 2019) conducted FMEA to examine malfunctions in the processes of an automobile spare parts manufacturer in Iran. Weights of FMEA components for defect types were determined with fuzzy BWM. Z-MOORA was used to prioritize errors with triangular fuzzy numbers and Z-numbers. Momen et al. (2019) used FMEA and fuzzy BWM to determine the criteria and priorities in a study evaluating the reasons for postponing surgeries in Iran. Ijadi Maghsoodi et al. (2019) used fuzzy BWM to find the aesthetic, technical, practical and cost main criteria and sub-criteria weights in the selection of speakers among four design prototypes, and FAD to select among alternative prototypes. Moslem et al. (2020) applied fuzzy BWM to evaluate the factors for three levels determined by a survey evaluating the factors according to the results of a driver behavior questionnaire for road safety in Romania. Karimi et al. (2020) included two applications comparing the results of full fuzzy BWM and fuzzy AHP results for the examination of the four criteria for employee recruitment and 8 main and 21 sub-criteria related to hospital care in Iran.

The studies involving SWARA and BWM methods together was also examined. Zavadskas et al. (2018) applied rough numbers with SWARA in the evaluation of the criteria to be considered in the selection of railway wagons. They compared their results with the same number type and the results they found with AHP and BWM. Zolfani and Chatterjee (2019) evaluated the criteria used in the assessment of home furnishing materials in terms of sustainable design with SWARA and BWM and compared the results of the two methods.

As a result of the comprehensive literature review; a study integrally using fuzzy SWARA for criteria weights, the fuzzy BWM method for alternative evaluation has not been encountered. In 
addition, as understood from the literature review; a supplier selection study discussing green, agile and Industry 4.0 as an evaluation dimension has also not been encountered.

\section{Methodology}

\subsection{Fuzzy SWARA}

Fuzzy SWARA follows the steps of the classic SWARA method defined by Keršuliene et al. (2010). The data type used in the evaluations is triangular fuzzy numbers. Fuzzy logic was used to reflect the DM opinions more accurately. SWARA was preferred because of it being recent, and the ease of use and calculation it provides. SWARA has n-1 pairwise comparisons. The method has less pairwise comparisons compared to the AHP method (Stanujkic et al. 2015). The steps of the method using fuzzy number data type instead of real numbers (Mavi et al. 2017):

Step 1. Ordering the selections: The selections that will be evaluated are ranked from most important to least important. When ranking for the $\mathrm{n}$ amount of selections on the list, it should be made sure that the most important selection is "1.", the least important is "n.".

Step 2. Finding the $\tilde{s}$ j value: It is the step that the selections that are ordered according to importance are compared. Starting from the second criteria in the importance ranking, comparisons are made with the criteria one step higher. The relative importance of the j. criteria compared to the $(\mathrm{j}-1)$. rank has been expressed to be "the comparative importance of average value" and is shown as $s_{j}$ (Keršulienè et al. 2010).

Step 3. Determining the $\tilde{k}_{\mathrm{j}}$ coefficient: It is the step in which the criteria in the first place is summed with $\tilde{1}$, and the other criteria are summed with the comparative importance of the determined $\tilde{s}_{\mathrm{j}}$ average respectively in Eq. (1).

$$
\left\{\begin{aligned}
\tilde{1} & j=1 \\
\tilde{s}_{j}+\tilde{1} & j>1
\end{aligned}\right.
$$

Step 4. Calculating the $\tilde{q}_{j}$ importance vector value: The fuzzy weights of the evaluated criteria are found in this step in Eq. (2).

$$
\left\{\begin{array}{cc}
\tilde{1} & j=1 \\
\frac{\tilde{x}_{j-1}}{\tilde{k}_{j}} & j>1
\end{array}\right.
$$

Step 5. Determining the $\widetilde{w}_{j}$ criteria weights: The criteria weights found in the last step of the fuzzy SWARA method are normalized and the ultimate fuzzy weights are found. The results are defuzzified and specific values are obtained in Eq. (3).

$\widetilde{w}_{j}=\frac{\tilde{q}_{j}}{\sum_{k=1}^{n} \tilde{q}_{k}}$ 
The mentioned operations are first done for the dimensions and the fuzzy weights of the dimensions will be found. Afterwards, they will be calculated for the criteria under the dimensions with SWARA, the local fuzzy weights found will be multiplied with the fuzzy weights of the dimensions and a separate global fuzzy weight will be obtained for each DM. Lastly, the arithmetic average of the global fuzzy weights of each DM will be taken to obtain a single opinion. The median value method was chosen for the defuzzification process because it does not contain excessive calculations and offers ease of use (Eq. 4):

$w=\frac{l+m+u}{3}$

The defuzzified fuzzy expressions are normalized to reach the final global weights of the criteria.

\subsection{Fuzzy BWM}

BWM is a MCDM method suggested by Rezaei (2015). It is based on the basic logic of determining the best/most demanded and the worst/least demanded alternatives among the selections to be evaluated and comparing them with other criteria (Rezaei 2015). It is a method that can be preferred because it is more consistent and requires less comparisons, and the results can be reached by applying the calculation steps with less information (Rezaei 2016). The fact that it does not have to create a full pairwise comparison matrix is a factor that reduces the number of calculations (Salimi and Rezaei 2018). Since BWM is quite new, it has not been used in many studies. The vectors created with the evaluations made according to the best and the worst, make it possible to check coherency. While AHP has n(n-1)/2 comparisons, BWM requires $2 n-3$ pairwise comparisons. The method (similar to SWARA) requiring fewer pairwise comparisons, provides results with fewer calculations (Rezaei 2015). The comparison structure of the BWM method can be seen in Figure 1.

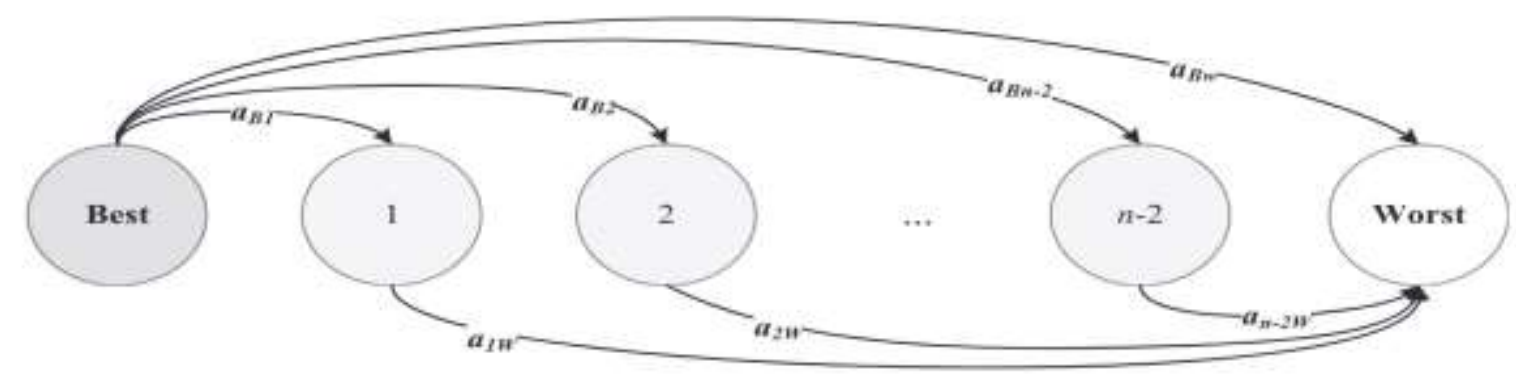

Fig. 1. The comparison structure in the BWM method (Rezaei 2015)

The BWM application consists of five steps:

Step 1. Determining the decision criteria to be evaluated. In the alternative selection application, the alternatives are similarly listed.

Step 2. The DM determines the best (the most important, most demanded) and worst (the least important, least demanded) among the alternatives. If there are more than one alternative thought to be the best or worst, a random one is chosen. 
Step 3. It is the proportional expression of the preference degree of the best alternative chosen by the DM compared to the other alternatives. Through the conducted evaluations, the BO vector (Best-to-Others vector) comparing the best with others is obtained and is shown with $A_{B}$ :

$$
A_{B}=\left(a_{B 1}, a_{B 2}, a_{B 3}, a_{B 4}, \ldots, a_{B n}\right)
$$

Here $a_{B 1}$ shows the preference degree of the best alternative compared to the 1 . alternative. Overall, it is possible to say that the expression $a_{B n}$ conveys the preference ratio between the best alternative and the $n$. alternative. The vector has 1 element since the best alternative will include an element to which it will be compared to $\left(a_{B B}=1\right)$.

Step 4. It is the proportional expression of the preference degree of all of the alternatives selected by the DM, except for the worst alternative, to the worst. Through the evaluations, the OW vector (Others-to-Worst vector) comparing the worst to the others is obtained $\left(A_{w}\right)$ :

$$
A_{W}=\left(a_{1 W}, a_{2 W}, a_{3 W}, a_{4 W}, \ldots, a_{n W}\right)
$$

Step 5. A linear programming model is established to find the weights of the alternatives. The weights are shown as $\left(w_{1}^{*}, w_{2}^{*}, w_{3}^{*}, w_{4}^{*}, \ldots, w_{n}^{*}\right)$. The optimal weights should be $w_{B} / w_{j}=a_{B j}$ and $w_{j} / w_{W}=a_{j W}$ for $w_{B}=w_{j}$ and $w_{j}=w_{W}$. The biggest absolute differences must be minimized to ensure the conditions. When the weight totals are 1 and the restriction of not taking a negative value are added (Eq. 5-12):

$$
\operatorname{minmax}_{j}\left\{\left|\frac{w_{B}}{w_{j}}-a_{B j}\right|,\left|\frac{w_{j}}{w_{W}}-a_{j W}\right|\right\}
$$

Restrictions:

$$
\begin{aligned}
& \sum_{j} w_{j}=1 \\
& W_{j} \geq 0, \forall_{j}
\end{aligned}
$$

The problem is transformed into a linear programming model.

$\min \xi$

Restrictions:

$$
\begin{aligned}
& \left|\frac{W_{B}}{W_{j}}-a_{B j}\right| \leq \xi, \forall_{j} \\
& \left|\frac{W_{j}}{W_{W}}-a_{j W}\right| \leq \xi, \forall_{j} \\
& \sum_{j} W_{j}=1 \\
& W_{j} \geq 0, \forall_{j}
\end{aligned}
$$


The optimal weights $\left(w_{1}^{*}, w_{2}^{*}, w_{3}^{*}, w_{4}^{*}, \ldots, w_{n}^{*}\right)$ and $\xi$ (consistency measure of the comparisons) values are calculated with the problem solution created (van de Kaa et al. 2018; Yadollahi et al. 2018). $\xi$ values are divided with the corresponding value in the consistency index (CI) shown in Table 2. In order to find the value in the consistency index table, the value in the BO vector of the alternative corresponding to one in the OW vector is looked at. Similarly, the value in the OW vector of the alternative corresponding to one in the BO vector gives the same result ( $\left.\mathrm{a}_{\mathrm{BW}}\right)$. The consistency ratio values are expected to be close to zero. It is accepted that the closer the value is to zero, the more consistent it is (Rezaei 2015). The consistency ratio is shown in Equation 13.

$C R=\frac{\xi^{*}}{C I}$

Table 2. Consistency index Table (Guo and Zhao 2017)

\begin{tabular}{|c|c|c|c|c|c|}
\hline $\mathrm{a}_{\mathrm{BW}}$ & EIM & WIM & FIM & VIM & AIM \\
\hline $\mathrm{CI}$ & 3.00 & 3.80 & 5.29 & 6.69 & 8.04 \\
\hline
\end{tabular}

The steps followed in the application are shown in Figure 2.
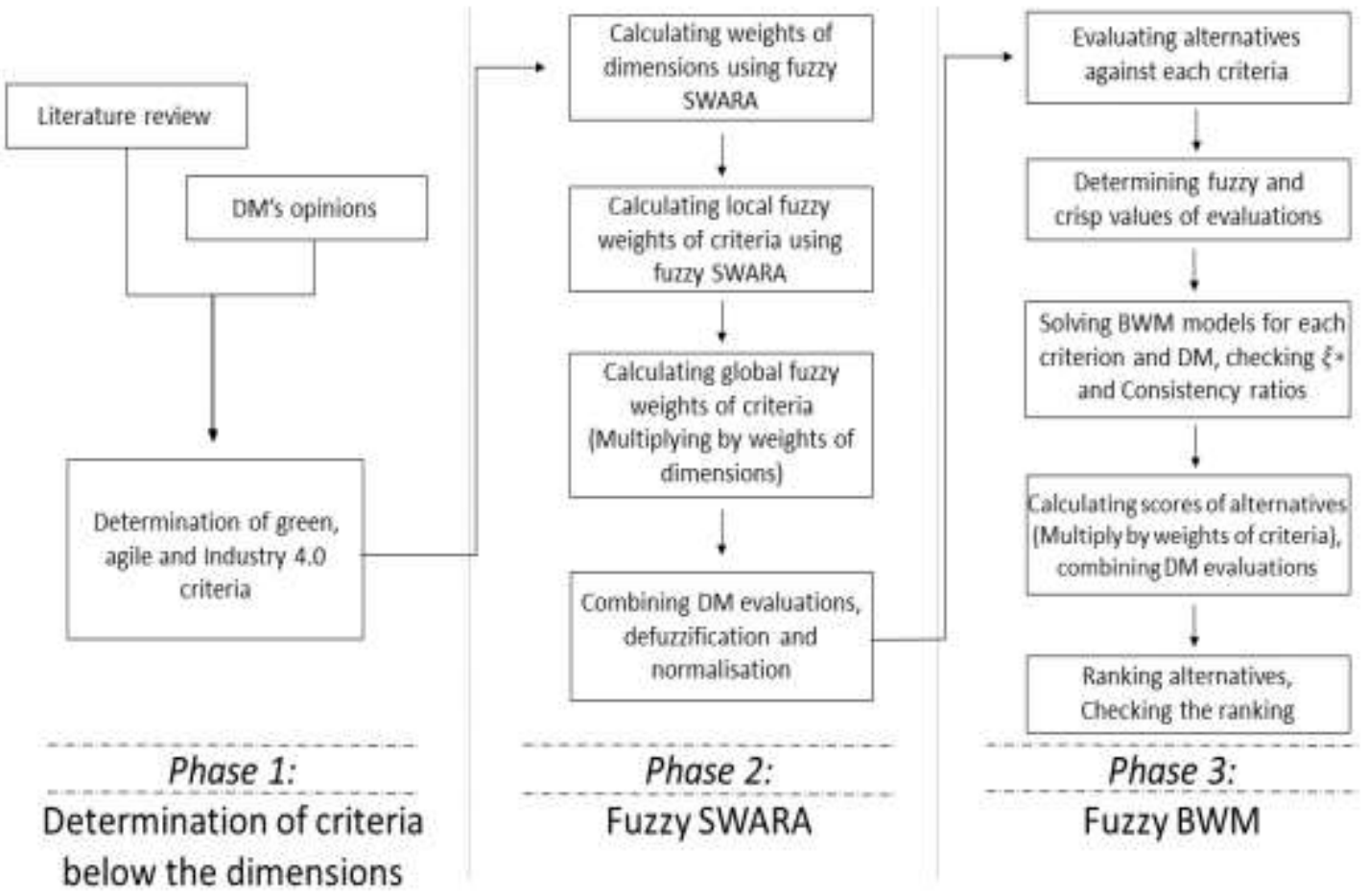

Fig. 2. The steps of the proposed methodology

\section{Case Study}

As the application subject, one of the largest plastic manufacturers in the Mediterranean region of Turkey was discussed. The business is one of the largest in the industry and has been manufacturing for large projects and individual consumers for over 50 years. It imports raw materials and semi-finished goods from various regions of the world, especially the People's 
Republic of China, and uses them in the manufacturing processes. It brings the manufactured products to the end consumer through vendors in the country. Also, it exports products to numerous countries.

The increasing environmental concern of today has also closely affected the plastic industry in which it is involved and has pushed the business to take responsibility in this regard. The business having the ISO 14001 Environmental Management System also expects the suppliers in its supply chain to abide by the standards in terms of the environment, respect nature and support the environmental performance of the business. The purpose of the business taking personalized product requests from customers through vendors is to provide customizable products and services according to the requests and expectations of the corporate customers in the business website, mobile application. The suppliers to work with being flexible suppliers increases the ability to respond to the rapidly changing requests and expectations of the consumers of the business. The business having the ISO/IEC 27001 Information Security Management System standards certification, wishes to adapt to the wind of change that the Industry 4.0 created in the entire world and makes investments to develop their processes with new technologies. As the new supplier selection model of the business, determining a supplier selection that is suitable for green, agile and Industry 4.0 were applied with MCDM methods. The three DM who were consulted are included in Table 3.

Table 3. Identification of DMs

\begin{tabular}{|c|c|c|c|}
\hline DM & Title & Education & Experience \\
\hline $\mathrm{DM}_{1}$ & Supply chain manager & Post graduate & 11 years \\
\hline $\mathrm{DM}_{2}$ & Purchasing manager & Graduate & 14 years \\
\hline $\mathrm{DM}_{3}$ & Project engineer & Graduate & 8 years \\
\hline
\end{tabular}

Alternatives will be evaluated with the fuzzy BWM, considering the weighted criteria one by one. By multiplying the obtained alternative evaluation results with the criteria weights, the values that the alternatives have in relation to the criteria will be calculated. The ordering of the alternatives will be determined according to the average of the total value of each alternative.

The main criteria to be used in the supplier selection application were divided into three criteria dimensions as; green $\left(\mathrm{B}_{1}\right)$, agile $\left(\mathrm{B}_{2}\right)$ and Industry $4.0\left(\mathrm{~B}_{3}\right)$. A wide literature review was conducted to select the evaluation measures to be included under the main criteria and DM opinions were also used (Table 4-6).

Table 4. Green supplier selection criteria

\begin{tabular}{|c|c|l|l|}
\hline $\begin{array}{c}\text { Green } \\
\text { criteria } \\
\left(\mathrm{C}_{1 \mathrm{n}}\right)\end{array}$ & Criteria & \multicolumn{1}{|c|}{ Definition } & References \\
\hline $\mathrm{C}_{11}$ & $\begin{array}{c}\text { Environmental } \\
\text { management } \\
\text { system }\end{array}$ & $\begin{array}{l}\text { The best known is ISO 14001. It is the certification system } \\
\text { developed for the purpose of proving the environmental } \\
\text { management skills of organization; to observe and manage } \\
\text { the environmental effects resulting from their activities } \\
\text { (Badri Ahmadi et al. 2017). }\end{array}$ & $\begin{array}{l}\text { (Kuo et } \\
2015), \quad \text { (Badri } \\
\text { Ahmadi et al. } \\
2017)\end{array}$ \\
\hline
\end{tabular}




\begin{tabular}{|c|c|l|l|}
\hline $\mathrm{C}_{12}$ & Green image & $\begin{array}{l}\text { It expresses the ability to prioritize manufacturing green } \\
\text { products in line with environmental standards and the } \\
\text { perception of this on the consumer (Mousakhani et al. } \\
\text { 2017). }\end{array}$ & $\begin{array}{l}\text { (Wang Chen et } \\
\text { al. 2016), } \\
\text { (Mousakhani } \\
\text { et al. 2017) }\end{array}$ \\
\hline $\mathrm{C}_{13}$ & $\begin{array}{c}\text { Pollution } \\
\text { control }\end{array}$ & $\begin{array}{l}\text { It is the control and monitoring of the pollution caused by } \\
\text { the activities of organizations in order not to harm nature } \\
\text { (Lin et al. 2017). }\end{array}$ & $\begin{array}{l}\text { (Lin et al. } \\
\text { 2017), (Wan et } \\
\text { al. 2017) }\end{array}$ \\
\hline $\mathrm{C}_{14}$ & $\begin{array}{c}\text { Management } \\
\text { commitment } \\
\text { and support }\end{array}$ & $\begin{array}{l}\text { It is having an environmentalist perspective and acting } \\
\text { with social responsibility within the organization, with the } \\
\text { support and encouragement of senior and mid-level } \\
\text { managers. }\end{array}$ & $\begin{array}{l}\text { (Jiang et al. } \\
\text { 2018), (Haeri } \\
\text { and Rezaei } \\
\text { 2019) }\end{array}$ \\
\hline $\mathrm{C}_{15}$ & $\begin{array}{l}\text { Reverse } \\
\text { logistics }\end{array}$ & $\begin{array}{l}\text { It is green activity, which expresses the increased value of } \\
\text { products being transported backwards from their final } \\
\text { destination (consumer) (Li et al. 2017). }\end{array}$ & $\begin{array}{l}\text { (Uygun and } \\
\text { Dede 2016), } \\
\text { (Liang and } \\
\text { Chong 2019) }\end{array}$ \\
\hline $\mathrm{C}_{16}$ & $\begin{array}{l}\text { Waste } \\
\text { management }\end{array}$ & $\begin{array}{l}\text { It expresses the suppliers reducing, measuring waste and } \\
\text { keeping it under surveillance throughout their activities } \\
\text { (Topaloglu et al. 2018). }\end{array}$ & $\begin{array}{l}\text { (Handfield et } \\
\text { al. 2002), } \\
\text { (Freeman and } \\
\text { Chen 2015) }\end{array}$ \\
\hline $\mathrm{C}_{17}$ & $\begin{array}{l}\text { Green } \\
\text { packaging }\end{array}$ & $\begin{array}{l}\text { It refers to the usage of environmentally friendly wrapping } \\
\text { and packing materials that will not negatively affect nature } \\
\text { by rapidly dissolving or degrading in nature (Kumar et al. } \\
\text { 2017). }\end{array}$ & $\begin{array}{l}\text { (Büyüközkan } \\
\text { and Çifçi } \\
\text { 2012), (Kumar } \\
\text { et al. 2017) }\end{array}$ \\
\hline
\end{tabular}

Table 5. Agile supplier selection criteria

\begin{tabular}{|c|c|l|l|}
\hline $\begin{array}{c}\text { Agile } \\
\text { criteria } \\
\left(\mathrm{C}_{2 n}\right)\end{array}$ & Criteria & \multicolumn{1}{|c|}{ Definition } & \multicolumn{1}{|c|}{ References } \\
\hline $\mathrm{C}_{21}$ & $\begin{array}{c}\text { Delivery } \\
\text { flexibility }\end{array}$ & $\begin{array}{l}\text { It is the degree to which the supplier can respond to changes } \\
\text { in the delivery requirements and adapt to changes in } \\
\text { planned delivery times (Aramyan et al. 2007; Lee et al. } \\
\text { 2015). }\end{array}$ & $\begin{array}{l}\text { (Gunasekaran } \\
\text { 1999), (Lee et } \\
\text { al. 2015) }\end{array}$ \\
\hline $\mathrm{C}_{22}$ & $\begin{array}{c}\text { Manufacturing } \\
\text { flexibility }\end{array}$ & $\begin{array}{l}\text { The ability to react to instant changes through the flexibility } \\
\text { shown in the manufacturing processes, increases the agility } \\
\text { of supply chains (Prater et al. 2001). }\end{array}$ & $\begin{array}{l}\text { (Gerwin } \\
\text { 1993), } \\
\text { (Alimardani et } \\
\text { al. 2013) }\end{array}$ \\
\hline $\mathrm{C}_{23}$ & $\begin{array}{l}\text { Resource } \\
\text { flexibility }\end{array}$ & $\begin{array}{l}\text { It is the ability to benefit effectively so as to meet changing } \\
\text { requirements in the supply of owned components } \\
\text { (Matawale et al. 2016). }\end{array}$ & $\begin{array}{l}\text { (Prater et al. } \\
\text { 2001), } \\
\text { (Matawale et } \\
\text { al. 2016) }\end{array}$ \\
\hline $\mathrm{C}_{24}$ & $\begin{array}{c}\text { Delivery } \\
\text { speed }\end{array}$ & $\begin{array}{l}\text { It is the degree to which the supplier meets the delivery } \\
\text { speed expectations (Lee et al. 2015). }\end{array}$ & $\begin{array}{l}\text { (Lee et al. } \\
\text { 2015), } \\
\text { (Beikkhakhian } \\
\text { et al. 2015) }\end{array}$ \\
\hline $\mathrm{C}_{25}$ & $\begin{array}{l}\text { Agile } \\
\text { customer } \\
\text { awareness }\end{array}$ & $\begin{array}{l}\text { It is the criteria suggesting a supplier's degree of the ability } \\
\text { to respond to customer demands (Lee et al. 2015). }\end{array}$ & $\begin{array}{l}\text { (Lee et al. } \\
\text { 2015) }\end{array}$ \\
\hline
\end{tabular}




\begin{tabular}{|c|c|l|l|}
\hline $\mathrm{C}_{26}$ & $\begin{array}{c}\text { Information } \\
\text { sharing }\end{array}$ & $\begin{array}{l}\text { It refers to the dynamic information sharing that will } \\
\text { increase the agility performance of a supplier by doing } \\
\text { network integration (Christopher 2000). }\end{array}$ & $\begin{array}{l}\text { (Christopher } \\
2000), \\
\text { (Galankashi et } \\
\text { al. 2016). }\end{array}$ \\
\hline $\mathrm{C}_{27}$ & $\begin{array}{c}\text { Cooperation } \\
\text { ability }\end{array}$ & $\begin{array}{l}\text { It expresses the supplier's degree of partnership with } \\
\text { supply chain entities in processes by providing process } \\
\text { integration (Matawale et al. 2016). }\end{array}$ & $\begin{array}{l}\text { (Matawale et } \\
\text { al. 2016), } \\
\text { (Sahu et al. } \\
2016)\end{array}$ \\
\hline
\end{tabular}

Table 6. Supplier selection criteria in line with Industry 4.0

\begin{tabular}{|c|c|c|c|}
\hline $\begin{array}{l}\text { Industry } \\
4.0 \\
\text { criteria } \\
\left(C_{3 n}\right)\end{array}$ & Criteria & Definition & References \\
\hline $\mathrm{C}_{31}$ & $\begin{array}{l}\text { Industry } 4.0 \\
\text { technology } \\
\text { usage }\end{array}$ & $\begin{array}{l}\text { It is the usage level of Industry } 4.0 \text { technologies such as } \\
\text { sensors, augmented reality, simulation etc. }\end{array}$ & $\begin{array}{l}\text { (Sachdeva et } \\
\text { al. 2019), } \\
\text { (Özbek and } \\
\text { Yildiz 2020) }\end{array}$ \\
\hline $\mathrm{C}_{32}$ & $\begin{array}{c}\text { Industry } 4.0 \\
\text { personnel }\end{array}$ & $\begin{array}{l}\text { It displays the Industry } 4.0 \text { usage skills and the level of } \\
\text { training of the employees. }\end{array}$ & $\begin{array}{l}\text { (Lichtblau et } \\
\text { al. 2014), } \\
\text { (Sharma and } \\
\text { Joshi 2020) }\end{array}$ \\
\hline $\mathrm{C}_{33}$ & $\begin{array}{c}\text { Digital customer } \\
\text { relationships }\end{array}$ & $\begin{array}{l}\text { It expresses the usage of customer data, thus the } \\
\text { digitalization of products and services. }\end{array}$ & $\begin{array}{l}\text { (Schumacher } \\
\text { et al. 2016) }\end{array}$ \\
\hline $\mathrm{C}_{34}$ & Smart factory & $\begin{array}{l}\text { It shows the obtained information and the possessed } \\
\text { innovative technological infrastructures, the level of } \\
\text { digitized manufacturing through information } \\
\text { technologies. }\end{array}$ & $\begin{array}{l}\text { (Lichtblau et } \\
\text { al. 2014) }\end{array}$ \\
\hline $\mathrm{C}_{35}$ & Cyber security & $\begin{array}{l}\text { It is the application of cyber security systems in order to } \\
\text { protect the data created during the processes (Sharma } \\
\text { and Joshi 2020). }\end{array}$ & $\begin{array}{l}\text { (Ghobakhloo } \\
\text { 2020), } \\
\text { (Sharma and } \\
\text { Joshi 2020) }\end{array}$ \\
\hline $\mathrm{C}_{36}$ & $\begin{array}{c}\text { Industry } 4.0 \\
\text { strategy }\end{array}$ & $\begin{array}{l}\text { It is the effort to make the business have the Industry } 4.0 \\
\text { strategy, and to create business models, operations and } \\
\text { the organization culture in line with Industry } 4.0 \text {. }\end{array}$ & $\begin{array}{l}\text { (Schumacher } \\
\text { et al. 2016), } \\
\text { (Salam, 2019) }\end{array}$ \\
\hline $\mathrm{C}_{37}$ & $\begin{array}{l}\text { Information } \\
\text { systems usage }\end{array}$ & $\begin{array}{l}\text { It refers to the big analysis, storage, integration and } \\
\text { management of the emerged big data. }\end{array}$ & $\begin{array}{l}\text { (Schuh et al. } \\
\text { 2017), (Özbek } \\
\text { and Yildiz } \\
\text { 2020) }\end{array}$ \\
\hline
\end{tabular}

The four alternative suppliers operating domestically and overseas were names as; $A_{1}, A_{2}, A_{3}$ and $\mathrm{A}_{4}$. The fuzzy number equivalents of the linguistic variables used by the three DMs to evaluate the dimensions and the criteria under them are given in Table 7 (Mavi et al. 2017; Sumrit 2020).

Table 7. The fuzzy number conversions of linguistic variables used in the criteria evaluation (Chang 1996) 


\begin{tabular}{|c|c|c|}
\hline Linguistic Variables & $\begin{array}{c}\text { Linguistic Variable } \\
\text { Codes }\end{array}$ & Fuzzy Numbers \\
\hline Equally Important & EI & $(1,1,1)$ \\
\hline Moderately Less Important & MI & $(2 / 3,1,3 / 2)$ \\
\hline Less Important & LI & $(2 / 5,1 / 2,2 / 3)$ \\
\hline Very Less Important & VI & $(2 / 7,1 / 3,2 / 5)$ \\
\hline Much Less Important & ML & $(2 / 9,1 / 4,2 / 7)$ \\
\hline
\end{tabular}

Firstly, the dimensions will be evaluated among themselves. It was asked that the DM ranked the dimensions from most important to least important. The dimension weights calculated with the DM evaluation and fuzzy SWARA are in Table 15 in Appendix.

Afterwards, the criteria under the dimensions were evaluated by the three DMs and their weights were determined with fuzzy SWARA. The green criteria evaluation of $\mathrm{DM}_{1}$ is in Table 16 in Appendix as an example.

The dimension weights of $\mathrm{DM}_{1}, \mathrm{DM}_{2}$ and $\mathrm{DM}_{3}$ determined with fuzzy SWARA are multiplied with the calculated criteria weights to find the fuzzy criteria weights. The arithmetic average of the calculated fuzzy numbers were taken to determine the final fuzzy weights (Table 8). The median method was used in the defuzzification calculation (Keshavarz Ghorabaee et al. 2018; Perçin 2019). The fuzzy numbers are turned into specific numbers and normalized to reach their final weight values. The final criteria weight values found are included in Table 9.

Table 8. The final fuzzy weights of the dimensions and criteria

\begin{tabular}{|c|c|c|c|c|c|}
\hline & Fuzzy Weights & & Fuzzy Weights & & Fuzzy Weights \\
\hline $\mathbf{D}_{1}$ & $(0.2232,0.2644,0.3158)$ & $\mathbf{D}_{2}$ & $(0.3816,0.4205,0.4647)$ & $\mathbf{D}_{3}$ & $\begin{array}{c}0.2697,0.3150, \\
0.3680)\end{array}$ \\
\hline $\mathrm{C}_{11}$ & $(0.0208,0.0363,0.0620)$ & $\mathrm{C}_{21}$ & $(0.0716,0.1025,0.1446)$ & $\mathrm{C}_{31}$ & $\begin{array}{c}0.0815,0.1099, \\
0.1490)\end{array}$ \\
\hline $\mathrm{C}_{12}$ & $(0.0199,0.0377,0.0667)$ & $\mathrm{C}_{22}$ & $(0.0329,0.0503,0.0764)$ & $\mathrm{C}_{32}$ & $\begin{array}{c}0.0272,0.0461, \\
0.0744)\end{array}$ \\
\hline $\mathrm{C}_{13}$ & $(0.0407,0.0516,0.0708)$ & $\mathrm{C}_{23}$ & $(0.0514,0.0685,0.0958)$ & $\mathrm{C}_{33}$ & $\begin{array}{c}0.0116,0.0232, \\
0.0431)\end{array}$ \\
\hline $\mathrm{C}_{14}$ & $(0.0198,0.0323,0.0527)$ & $\mathrm{C}_{24}$ & $(0.0966,0.1273,0.1700)$ & $\mathrm{C}_{34}$ & $\begin{array}{c}0.0252,0.0422, \\
0.0688)\end{array}$ \\
\hline $\mathrm{C}_{15}$ & $(0.0418,0.0571,0.0786)$ & $\mathrm{C}_{25}$ & $(0.0102,0.0201,0.0371)$ & $\mathrm{C}_{35}$ & $\begin{array}{c}0.0261,0.0438, \\
0.0715)\end{array}$ \\
\hline $\mathrm{C}_{16}$ & $(0.0234,0.0321,0.0467)$ & $\mathrm{C}_{26}$ & $(0.0087,0.0200,0.0406)$ & $\mathrm{C}_{36}$ & $\begin{array}{c}0.0147,0.0293, \\
0.0534)\end{array}$ \\
\hline $\mathrm{C}_{17}$ & $(0.0083,0.0171,0.0342)$ & $\mathrm{C}_{27}$ & $(0.0176,0.0314,0.0541)$ & $\mathrm{C}_{37}$ & $\begin{array}{c}0.0117,0.0202, \\
0.0350)\end{array}$ \\
\hline
\end{tabular}

Table 9. The final weights of the dimensions and criteria

\begin{tabular}{|c|c|c|c|c|c|}
\hline Dimension & Global Weight & Dimension & Global Weight & Dimension & Global Weight \\
\hline $\mathrm{D}_{1}$ & 0.2658 & $\mathrm{D}_{2}$ & 0.4191 & $\mathrm{D}_{3}$ & 0.3151 \\
\hline
\end{tabular}




\begin{tabular}{|l|l|l|l|l|l|}
\hline $\mathrm{C}_{11}$ & 0.0374 & $\mathrm{C}_{21}$ & 0.1000 & $\mathrm{C}_{31}$ & 0.1068 \\
\hline $\mathrm{C}_{12}$ & 0.0390 & $\mathrm{C}_{22}$ & 0.0501 & $\mathrm{C}_{32}$ & 0.0464 \\
\hline $\mathrm{C}_{13}$ & 0.0512 & $\mathrm{C}_{23}$ & 0.0677 & $\mathrm{C}_{33}$ & 0.0245 \\
\hline $\mathrm{C}_{14}$ & 0.0329 & $\mathrm{C}_{24}$ & 0.1236 & $\mathrm{C}_{34}$ & 0.0428 \\
\hline $\mathrm{C}_{15}$ & 0.0557 & $\mathrm{C}_{25}$ & 0.0212 & $\mathrm{C}_{35}$ & 0.0444 \\
\hline $\mathrm{C}_{16}$ & 0.0321 & $\mathrm{C}_{26}$ & 0.0218 & $\mathrm{C}_{36}$ & 0.0306 \\
\hline $\mathrm{C}_{17}$ & 0.0187 & $\mathrm{C}_{27}$ & 0.0324 & $\mathrm{C}_{37}$ & 0.0210 \\
\hline
\end{tabular}

The weights of the dimensions and criteria were found with fuzzy SWARA. The most important dimension was the agility dimension with the final weight of 0.4191 . The dimension ranking second was the Industry 4.0 with 0.3151 , the last one was the green dimension with 0.2658 . It was seen that the most important criteria was delivery speed $\left(\mathrm{C}_{24}\right)$. The most important second criteria was the usage of Industry 4.0 technologies $\left(\mathrm{C}_{31}\right)$, the third was delivery flexibility $\left(\mathrm{C}_{21}\right)$, the fourth was resource flexibility $\left(\mathrm{C}_{23}\right)$ and the fifth was reverse logistics $\left(\mathrm{C}_{15}\right)$. The criteria weights and ranking is shown in Table 10.

Table 10. The ranking of criteria weights

\begin{tabular}{|c|c|c|c|c|c|c|c|c|}
\hline $\mathrm{D}_{1}$ & Weight & Rank & $\mathrm{D}_{2}$ & Weight & Rank & $\mathrm{D}_{3}$ & Weight & Rank \\
\hline $\mathrm{D}_{1}$ & 0.2658 & 3 & $\mathrm{D}_{2}$ & 0.4191 & 1 & $\mathrm{D}_{3}$ & 0.3151 & 2 \\
\hline $\mathrm{C}_{11}$ & 0.0374 & 12 & $\mathrm{C}_{21}$ & 0.1000 & 3 & $\mathrm{C}_{31}$ & 0.1068 & 2 \\
\hline $\mathrm{C}_{12}$ & 0.0390 & 11 & $\mathrm{C}_{22}$ & 0.0501 & 7 & $\mathrm{C}_{32}$ & 0.0464 & 8 \\
\hline $\mathrm{C}_{13}$ & 0.0512 & 6 & $\mathrm{C}_{23}$ & 0.0677 & 4 & $\mathrm{C}_{33}$ & 0.0245 & 17 \\
\hline $\mathrm{C}_{14}$ & 0.0329 & 13 & $\mathrm{C}_{24}$ & 0.1236 & 1 & $\mathrm{C}_{34}$ & 0.0428 & 10 \\
\hline $\mathrm{C}_{15}$ & 0.0557 & 5 & $\mathrm{C}_{25}$ & 0.0212 & 19 & $\mathrm{C}_{35}$ & 0.0444 & 9 \\
\hline $\mathrm{C}_{16}$ & 0.0321 & 15 & $\mathrm{C}_{26}$ & 0.0218 & 18 & $\mathrm{C}_{36}$ & 0.0306 & 16 \\
\hline $\mathrm{C}_{17}$ & 0.0187 & 21 & $\mathrm{C}_{27}$ & 0.0324 & 14 & $\mathrm{C}_{37}$ & 0.0210 & 20 \\
\hline
\end{tabular}

The three most important criteria among the criteria in the green dimension are reverse logistics $\left(\mathrm{C}_{15}\right)$, pollution control $\left(\mathrm{C}_{13}\right)$ and green image $\left(\mathrm{C}_{12}\right)$, respectively. The order of the criteria in the green dimension:

$$
\mathrm{C}_{15}>\mathrm{C}_{13}>\mathrm{C}_{12}>\mathrm{C}_{11}>\mathrm{C}_{14}>\mathrm{C}_{16}>\mathrm{C}_{17}
$$

The most important criteria in the agility dimension, delivery speed $\left(\mathrm{C}_{24}\right)$, was also found to be the criteria with the highest value among the 21 criteria. The order of the criteria in the agility dimension:

$$
\mathrm{C}_{24}>\mathrm{C}_{21}>\mathrm{C}_{23}>\mathrm{C}_{22}>\mathrm{C}_{27}>\mathrm{C}_{26}>\mathrm{C}_{25}
$$

The most important criteria in the Industry 4.0 dimension is the usage of Industry 4.0 technologies $\left(\mathrm{C}_{31}\right)$. The order of the criteria in this dimension:

$$
\mathrm{C}_{31}>\mathrm{C}_{32}>\mathrm{C}_{35}>\mathrm{C}_{34}>\mathrm{C}_{36}>\mathrm{C}_{33}>\mathrm{C}_{37}
$$


Fuzzy BWM was used to examine alternatives in the second part of the study. The three DMs evaluated the four alternative suppliers with the help of linguistic variables. The fuzzy number conversions for the linguistic variables used are shown in Table 11. The three DMs determined the best and worst alternatives for each criterion (Table 17 in Appendix).

Table 11. The fuzzy number conversions of the linguistic variables used in the evaluation of alternatives (Guo and Zhao 2017; Omrani et al. 2018)

\begin{tabular}{|c|c|c|}
\hline Linguistic Variables & Code & Fuzzy Number \\
\hline Equally Importance & EIM & $(1,1,1)$ \\
\hline Weakly Important & WIM & $(2 / 3,1,3 / 2)$ \\
\hline Fairly Important & FIM & $(3 / 2,2,5 / 2)$ \\
\hline Very Important & VIM & $(5 / 2,3,7 / 2)$ \\
\hline Absolutely Important & AIM & $(7 / 2,4,9 / 2)$ \\
\hline
\end{tabular}

Afterwards, the linguistic evaluations that will make up the BO and OW vectors were carried out by the three DMs for each criterion. The linguistic evaluations were taken from Table 11. The fuzzy number equivalents and defuzzified values of the evaluations were found with the median method. The evaluation of the alternatives in relation to green image $\left(\mathrm{C}_{12}\right)$ by $\mathrm{DM}_{1}$ is seen in Table 18 and Table 19 in Appendix as an example. Considering the created evaluation Tables, a total of 63 BWM models were established for the three DMs. The solutions of the models established for $\mathrm{DM}_{1}, \mathrm{DM}_{2}$ and $\mathrm{DM}_{3}$ and the alternative evaluation results found, $\xi^{*}$ values and consistency ratios are included in Table 20 in Appendix, subsequently.

As the consistency ratios found were quite close to zero, the results can be accepted as consistent. Later in the application, the results were combined by multiplying the criteria weights found with the fuzzy SWARA method with the alternative evaluation results determined with the fuzzy BWM. The total scores of the alternatives are in the bottom total row (Table 12).

The final evaluation results of the alternatives are revealed by taking the arithmetic average of the total values found for each DM (Table 13).

Table 12. Combining the fuzzy SWARA and fuzzy BWM results

\begin{tabular}{|c|c|c|c|c|c|c|c|c|c|c|c|c|}
\hline & \multicolumn{5}{|c|}{$\mathrm{DM}_{1}$} & \multicolumn{4}{c|}{$\mathrm{DM}_{2}$} & \multicolumn{4}{c|}{$\mathrm{DM}_{3}$} \\
\hline & $\mathrm{A}_{1}$ & $\mathrm{~A}_{2}$ & $\mathrm{~A}_{3}$ & $\mathrm{~A}_{4}$ & $\mathrm{~A}_{1}$ & $\mathrm{~A}_{2}$ & $\mathrm{~A}_{3}$ & $\mathrm{~A}_{4}$ & $\mathrm{~A}_{1}$ & $\mathrm{~A}_{2}$ & $\mathrm{~A}_{3}$ & $\mathrm{~A}_{4}$ \\
\hline $\mathrm{C}_{11}$ & 0.0093 & 0.0164 & 0.0071 & 0.0046 & 0.0047 & 0.0137 & 0.0113 & 0.0077 & 0.0067 & 0.0179 & 0.0077 & 0.0051 \\
\hline $\mathrm{C}_{12}$ & 0.0100 & 0.0066 & 0.0183 & 0.0042 & 0.0048 & 0.0173 & 0.0101 & 0.0067 & 0.0078 & 0.0195 & 0.0078 & 0.0039 \\
\hline $\mathrm{C}_{13}$ & 0.0102 & 0.0102 & 0.0256 & 0.0051 & 0.0131 & 0.0087 & 0.0240 & 0.0054 & 0.0049 & 0.0219 & 0.0122 & 0.0122 \\
\hline $\mathrm{C}_{14}$ & 0.0050 & 0.0120 & 0.0084 & 0.0075 & 0.0078 & 0.0141 & 0.0078 & 0.0031 & 0.0041 & 0.0082 & 0.0157 & 0.0050 \\
\hline $\mathrm{C}_{15}$ & 0.0182 & 0.0208 & 0.0111 & 0.0056 & 0.0100 & 0.0151 & 0.0230 & 0.0075 & 0.0057 & 0.0212 & 0.0128 & 0.0159 \\
\hline $\mathrm{C}_{16}$ & 0.0122 & 0.0074 & 0.0033 & 0.0092 & 0.0096 & 0.0031 & 0.0137 & 0.0057 & 0.0080 & 0.0141 & 0.0061 & 0.0040 \\
\hline $\mathrm{C}_{17}$ & 0.0019 & 0.0037 & 0.0094 & 0.0037 & 0.0021 & 0.0054 & 0.0070 & 0.0042 & 0.0034 & 0.0051 & 0.0077 & 0.0025 \\
\hline $\mathrm{C}_{21}$ & 0.0229 & 0.0152 & 0.0255 & 0.0363 & 0.0376 & 0.0291 & 0.0222 & 0.0111 & 0.0203 & 0.0102 & 0.0385 & 0.0310 \\
\hline $\mathrm{C}_{22}$ & 0.0177 & 0.0125 & 0.0074 & 0.0125 & 0.0101 & 0.0079 & 0.0101 & 0.0220 & 0.0191 & 0.0158 & 0.0044 & 0.0108 \\
\hline
\end{tabular}




\begin{tabular}{|c|c|c|c|c|c|c|c|c|c|c|c|c|}
\hline $\mathrm{C}_{23}$ & 0.0246 & 0.0173 & 0.0103 & 0.0155 & 0.0240 & 0.0168 & 0.0101 & 0.0168 & 0.0251 & 0.0109 & 0.0071 & 0.0247 \\
\hline $\mathrm{C}_{24}$ & 0.0319 & 0.0136 & 0.0231 & 0.0550 & 0.0469 & 0.0153 & 0.0307 & 0.0307 & 0.0530 & 0.0118 & 0.0294 & 0.0294 \\
\hline $\mathrm{C}_{25}$ & 0.0062 & 0.0047 & 0.0024 & 0.0080 & 0.0106 & 0.0021 & 0.0042 & 0.0042 & 0.0066 & 0.0022 & 0.0082 & 0.0043 \\
\hline $\mathrm{C}_{26}$ & 0.0059 & 0.0040 & 0.0020 & 0.0099 & 0.0054 & 0.0054 & 0.0027 & 0.0083 & 0.0045 & 0.0108 & 0.0022 & 0.0043 \\
\hline $\mathrm{C}_{27}$ & 0.0110 & 0.0030 & 0.0080 & 0.0103 & 0.0139 & 0.0062 & 0.0046 & 0.0077 & 0.0080 & 0.0123 & 0.0080 & 0.0040 \\
\hline $\mathrm{C}_{31}$ & 0.0119 & 0.0237 & 0.0401 & 0.0311 & 0.0094 & 0.0408 & 0.0230 & 0.0336 & 0.0119 & 0.0237 & 0.0237 & 0.0475 \\
\hline $\mathrm{C}_{32}$ & 0.0039 & 0.0193 & 0.0155 & 0.0077 & 0.0044 & 0.0197 & 0.0139 & 0.0083 & 0.0085 & 0.0171 & 0.0145 & 0.0063 \\
\hline $\mathrm{C}_{33}$ & 0.0032 & 0.0053 & 0.0076 & 0.0083 & 0.0064 & 0.0040 & 0.0115 & 0.0026 & 0.0062 & 0.0115 & 0.0026 & 0.0042 \\
\hline $\mathrm{C}_{34}$ & 0.0078 & 0.0039 & 0.0194 & 0.0117 & 0.0097 & 0.0179 & 0.0097 & 0.0055 & 0.0048 & 0.0124 & 0.0161 & 0.0095 \\
\hline $\mathrm{C}_{35}$ & 0.0044 & 0.0166 & 0.0145 & 0.0089 & 0.0089 & 0.0089 & 0.0222 & 0.0044 & 0.0115 & 0.0198 & 0.0083 & 0.0049 \\
\hline $\mathrm{C}_{36}$ & 0.0048 & 0.0062 & 0.0062 & 0.0134 & 0.0031 & 0.0061 & 0.0061 & 0.0153 & 0.0076 & 0.0076 & 0.0116 & 0.0038 \\
\hline $\mathrm{C}_{37}$ & 0.0030 & 0.0040 & 0.0090 & 0.0050 & 0.0060 & 0.0048 & 0.0080 & 0.0022 & 0.0022 & 0.0080 & 0.0048 & 0.0060 \\
\hline Tot. & 0.2260 & 0.2264 & 0.2742 & 0.2734 & 0.2485 & 0.2626 & 0.2759 & 0.2130 & 0.2297 & 0.2817 & 0.2494 & 0.2392 \\
\hline
\end{tabular}

Table 13. The evaluation results of the alternatives

\begin{tabular}{|c|c|c|c|c|}
\hline & $\mathrm{DM}_{1}$ & $\mathrm{DM}_{2}$ & $\mathrm{DM}_{3}$ & Average \\
\hline $\mathrm{A}_{1}$ & 0.2260 & 0.2485 & 0.2297 & 0.2347 \\
\hline $\mathrm{A}_{2}$ & 0.2264 & 0.2626 & 0.2817 & 0.2569 \\
\hline $\mathrm{A}_{3}$ & 0.2742 & 0.2759 & 0.2494 & 0.2665 \\
\hline $\mathrm{A}_{4}$ & 0.2734 & 0.2130 & 0.2392 & 0.2419 \\
\hline
\end{tabular}

As a result of the applied methods, the best alternative supplier was found as $A_{3}$. The order of the suppliers were found as $A_{3}>A_{2}>A_{4}>A_{1}$. In the sensitivity analysis study, scenarios were created by changing the weights of the criteria under the dimensions. In Table 14, the alternative ranking created as a result of 21 different scenarios were shown and the results were compared. As a result of the assessments, it was seen that the order did not change, the order remained the same. The rankings created as a result of the scenarios are seen in Figure 3. In this figure, the scores of alternatives in 21 different scenarios were illustrated (Scores on $\mathrm{x}$ axis, scenarios and average on y axis).

Table 14. Comparing the results

\begin{tabular}{|c|c|c|c|c|c|}
\hline Scenarios & $\mathrm{A}_{1}$ & $\mathrm{~A}_{2}$ & $\mathrm{~A}_{3}$ & $\mathrm{~A}_{4}$ & Ranking \\
\hline S01 & 0.2347 & 0.2588 & 0.2635 & 0.2430 & $\mathrm{~A}_{3}>\mathrm{A}_{2}>\mathrm{A}_{4}>\mathrm{A}_{1}$ \\
\hline $\mathrm{S} 02$ & 0.2365 & 0.2558 & 0.2650 & 0.2428 & $\mathrm{~A}_{3}>\mathrm{A}_{2}>\mathrm{A}_{4}>\mathrm{A}_{1}$ \\
\hline $\mathrm{S} 03$ & 0.2344 & 0.2525 & 0.2702 & 0.2428 & $\mathrm{~A}_{3}>\mathrm{A}_{2}>\mathrm{A}_{4}>\mathrm{A}_{1}$ \\
\hline S04 & 0.2347 & 0.2550 & 0.2686 & 0.2418 & $\mathrm{~A}_{3}>\mathrm{A}_{2}>\mathrm{A}_{4}>\mathrm{A}_{1}$ \\
\hline S05 & 0.2363 & 0.2549 & 0.2653 & 0.2435 & $\mathrm{~A}_{3}>\mathrm{A}_{2}>\mathrm{A}_{4}>\mathrm{A}_{1}$ \\
\hline S06 & 0.2370 & 0.2598 & 0.2622 & 0.2410 & $\mathrm{~A}_{3}>\mathrm{A}_{2}>\mathrm{A}_{4}>\mathrm{A}_{1}$ \\
\hline S07 & 0.2362 & 0.2589 & 0.2632 & 0.2417 & $\mathrm{~A}_{3}>\mathrm{A}_{2}>\mathrm{A}_{4}>\mathrm{A}_{1}$ \\
\hline S08 & 0.2358 & 0.2609 & 0.2664 & 0.2369 & $\mathrm{~A}_{3}>\mathrm{A}_{2}>\mathrm{A}_{4}>\mathrm{A}_{1}$ \\
\hline S09 & 0.2391 & 0.2529 & 0.2659 & 0.2422 & $\mathrm{~A}_{3}>\mathrm{A}_{2}>\mathrm{A}_{4}>\mathrm{A}_{1}$ \\
\hline S10 & 0.2254 & 0.2710 & 0.2603 & 0.2433 & $\mathrm{~A}_{2}>\mathrm{A}_{3}>\mathrm{A}_{4}>\mathrm{A}_{1}$ \\
\hline S11 & 0.2422 & 0.2509 & 0.2709 & 0.2360 & $\mathrm{~A}_{3}>\mathrm{A}_{2}>\mathrm{A}_{1}>\mathrm{A}_{4}$ \\
\hline
\end{tabular}




\begin{tabular}{|c|l|l|l|l|l|}
\hline S12 & 0.2430 & 0.2532 & 0.2663 & 0.2376 & $\mathrm{~A}_{3}>\mathrm{A}_{2}>\mathrm{A}_{1}>\mathrm{A}_{4}$ \\
\hline $\mathrm{S} 13$ & 0.2399 & 0.2546 & 0.2727 & 0.2328 & $\mathrm{~A}_{3}>\mathrm{A}_{2}>\mathrm{A}_{1}>\mathrm{A}_{4}$ \\
\hline S14 & 0.2420 & 0.2579 & 0.2718 & 0.2283 & $\mathrm{~A}_{3}>\mathrm{A}_{2}>\mathrm{A}_{1}>\mathrm{A}_{4}$ \\
\hline S15 & 0.2412 & 0.2542 & 0.2716 & 0.2330 & $\mathrm{~A}_{3}>\mathrm{A}_{2}>\mathrm{A}_{1}>\mathrm{A}_{4}$ \\
\hline S16 & 0.2476 & 0.2551 & 0.2632 & 0.2341 & $\mathrm{~A}_{3}>\mathrm{A}_{2}>\mathrm{A}_{1}>\mathrm{A}_{4}$ \\
\hline S17 & 0.2450 & 0.2487 & 0.2732 & 0.2330 & $\mathrm{~A}_{3}>\mathrm{A}_{2}>\mathrm{A}_{1}>\mathrm{A}_{4}$ \\
\hline S18 & 0.2369 & 0.2718 & 0.2559 & 0.2354 & $\mathrm{~A}_{2}>\mathrm{A}_{3}>\mathrm{A}_{1}>\mathrm{A}_{4}$ \\
\hline S19 & 0.2433 & 0.2497 & 0.2607 & 0.2463 & $\mathrm{~A}_{3}>\mathrm{A}_{2}>\mathrm{A}_{4}>\mathrm{A}_{1}$ \\
\hline S20 & 0.2391 & 0.2571 & 0.2690 & 0.2348 & $\mathrm{~A}_{3}>\mathrm{A}_{2}>\mathrm{A}_{1}>\mathrm{A}_{4}$ \\
\hline S21 & 0.2367 & 0.2609 & 0.2539 & 0.2485 & $\mathrm{~A}_{2}>\mathrm{A}_{3}>\mathrm{A}_{4}>\mathrm{A}_{1}$ \\
\hline Average & 0.2384 & 0.2569 & 0.2657 & 0.2390 & $\mathrm{~A}_{3}>\mathrm{A}_{2}>\mathrm{A}_{4}>\mathrm{A}_{1}$ \\
\hline
\end{tabular}

Fig. 3. Rankings resulting from the scenarios

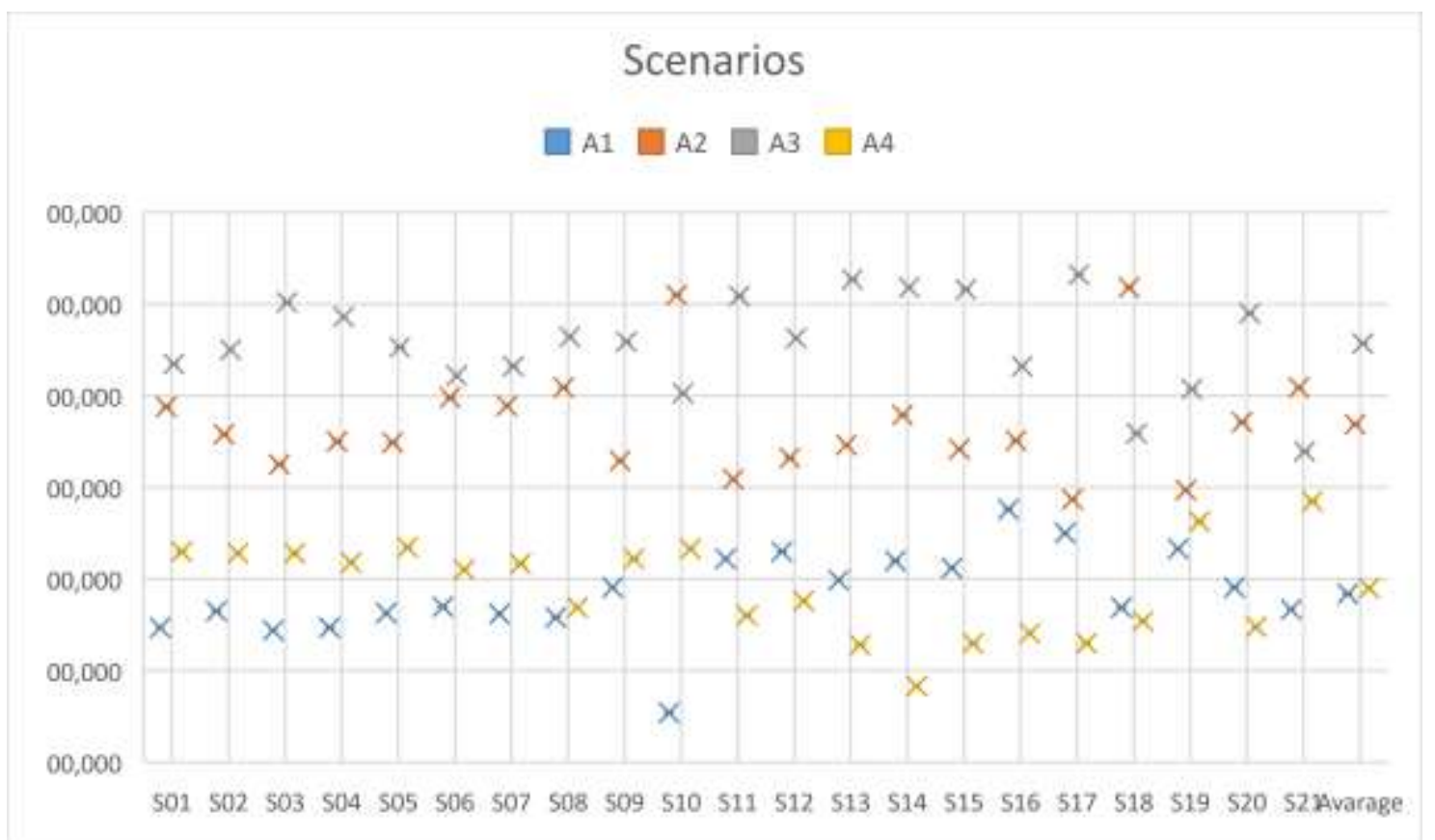

\section{Conclusion}

Businesses encounter many difficulties when selecting supplier to be a part of their supply chains. In order to overcome these difficulties, a supplier selection application was conducted in the study using two MCDM methods holistically. The topics considered by a plastic product manufacturer selected as the application subject during the selection process were collected in three dimensions as, green, agility and Industry 4.0. Triangular fuzzy numbers were preferred in order to reflect DM opinions appropriately.

According to the fuzzy SWARA method used in determining the weights of dimensions and criteria, the most important dimension is the agility dimension. The most important criteria are delivery speed, the usage of Industry 4.0 technologies and delivery flexibility, respectively. This situation shows that the businesses in the plastic product market find it important to establish agile supply chains. In order to ensure fast response, which is one of the most important benefits 
of the agile supply chain, the supplier must have high delivery speed and the flexibility to adapt to the changing conditions. In this sense, it seems that the results are consistent. It was seen that the second most important criteria was the usage of Industry 4.0 technologies. It was observed that the business was aware of the advantages that the Industry 4.0 technologies provide. The other criteria in the Industry 4.0 dimension having relatively low scores suggest that the business perceives Industry 4.0 transformation mostly as involving technological advancements into processes. The criteria with the highest weights in the green dimension ranking last were reverse logistics, pollution control and green image. The business has high capability in terms of reverse logistics, is able to manage the pollution it causes and has a tendency to choose suppliers that will contribute to the green image of the business. It is seen that the suppliers should make an effort to prevent the damage that the plastic product in question causes to nature and recycle it.

The results found at the end of the methodology application were compared to the results of other studies in the literature. In a study they conducted on agile supplier selection, Beikkhakhian et al. (2015) found the most important criteria as delivery speed, cost minimization and price, respectively. Similarly, delivery speed had a weight result that was quite high among the 10 criteria evaluated. Sachdeva et al. (2019) found that for an automobile manufacturer in India, the usage of Industry 4.0 technologies was the highest among the five criteria considered in the supplier selection to compete in the Industry 4.0 era. In this study, the same criteria was ranked in second place with a high weight value once again. Matawale et al. (2016) found resource flexibility as the most important criteria in the agile supplier selection application; Dursun (2017) found that resource flexibility was one of the criteria with the highest conversion weight value in an agile supplier selection study. In this study, the same criteria was in fourth place in the weight result ranking. When this study is evaluated together with the aforementioned studies, it is possible to say that the criteria weight ranking is consistent.

According to the result of the BWM method used in the evaluation of suppliers, the alternative $\mathrm{A}_{3}$ was found to be the alternative with the highest value. $A_{4}$ and $A_{1}$ followed $A_{2}$, which was in second place. The average of the results from the 21 scenarios created displayed that the ranking did not change.

It is thought that it would be appropriate to increase the number of DMs in order to expand the scope of the application in future studies. Increasing the number of evaluation dimensions and criteria, along with the number of alternative suppliers, are among changes that could be done to broaden the scope. In addition to the methods used and triangular fuzzy numbers; it would be possible to make comparisons between results through using gray numbers, Z-numbers etc. with other MCDM methods in the literature.

\section{Declarations}

\section{Compliance with Ethical Standards}

Ethical approval: This article does not contain any studies with human participants or animals performed.

The authors did not receive support from any organization for this study.

Conflict of Interest: The authors declare that they have no conflict of interest. 
Informed Consent: Not applicable.

\section{Authorship contributions}

Authors contributed equally to this work.

\section{References}

Abdelilah B, El Korchi A, Balambo MA (2018) Flexibility and agility: evolution and relationship. J Manuf Technol Manag 29(7):1138-1162. https://doi.org/10.1108/JMTM-03-2018-0090

Abdollahi M, Arvan M, Razmi J (2015) An integrated approach for supplier portfolio selection: Lean or agile? Expert Syst Appl 42(1): 679-690. https://doi.org/10.1016/j.eswa.2014.08.019

Akcan S, Taş MA (2019) Green supplier evaluation with SWARA-TOPSIS integrated method to reduce ecological risk factors. Environ Monit Assess 191(12):1-12. https://doi.org/10.1007/s10661-019-7884-3

Alimardani M, Hashemkhani Zolfani S, Aghdaie MH, Tamošaitienè J (2013) A novel hybrid SWARA and VIKOR methodology for supplier selection in an agile environment. Technol Econ Dev Econ 19(3): 533-548. https://doi.org/10.3846/20294913.2013.814606

Aramyan LH, Lansink AGO, Van Der Vorst JG, Van Kooten O (2007) Performance measurement in agri-food supply chains: A case study. Supply Chain Manag 12(4):304-315. https://doi.org/10.1108/13598540710759826

Badri Ahmadi H, Hashemi Petrudi SH, Wang X (2017) Integrating sustainability into supplier selection with analytical hierarchy process and improved grey relational analysis: a case of telecom industry. Int J Adv Manuf Technol 90(9):2413-2427. https://doi.org/10.1007/s00170-016-9518-z

Banaeian N, Mobli H, Fahimnia B, Nielsen IE, Omid M (2018) Green supplier selection using fuzzy group decision making methods: A case study from the agri-food industry. Comput Oper Res 89:337-347. https://doi.org/10.1016/j.cor.2016.02.015

Beikkhakhian Y, Javanmardi M, Karbasian M, Khayambashi B (2015) The application of ISM model in evaluating agile suppliers selection criteria and ranking suppliers using fuzzy TOPSIS-AHP methods. Expert Syst Appl 42(15-16):6224-6236. https://doi.org/10.1016/j.eswa.2015.02.035

Bongomin O, Yemane A, Kembabazi B, Malanda C, Chikonkolo Mwape M, Sheron Mpofu N, Tigalana D (2020) Industry 4.0 Disruption and Its Neologisms in Major Industrial Sectors: A State of the Art. J Eng 2020: 8090521. https://doi.org/10.1155/2020/8090521

Bottani E (2010) Profile and enablers of agile companies: An empirical investigation. Int J Prod Econ 125(2):251-261. https://doi.org/10.1016/j.ijpe.2010.02.016

Büyüközkan G, Arsenyan J (2009) Supplier selection in an agile supply chain environment using fuzzy axiomatic design approach. IFAC Proc Vol (IFAC-PapersOnline), 42(4):840-845. https://doi.org/10.3182/20090603-3-RU-2001.0504

Büyüközkan G, Çifçi G (2012) A novel hybrid MCDM approach based on fuzzy DEMATEL, fuzzy ANP and fuzzy TOPSIS to evaluate green suppliers. Expert Syst Appl 39(3):3000-3011. https://doi.org/10.1016/j.eswa.2011.08.162

Büyüközkan G, Göçer F (2018) An extension of ARAS methodology under Interval Valued Intuitionistic Fuzzy environment for Digital Supply Chain. Appl Soft Comput 69:634-654. https://doi.org/10.1016/j.asoc.2018.04.040 
Chang DY (1996) Applications of the extent analysis method on fuzzy AHP. Eur J Oper Res 95(3):649-655. https://doi.org/10.1016/0377-2217(95)00300-2

Christopher M (2000) The Agile Supply Chain: Competing in Volatile Markets. Ind Mark Manag 29(1):3744. https://doi.org/10.1016/S0019-8501(99)00110-8

Dossou PE, Nachidi M (2017) Modeling Supply Chain Performance. Procedia Manuf 11:838-845. https://doi.org/10.1016/j.promfg.2017.07.186

Dotoli M, Epicoco N, Falagario M (2015) Integrated supplier selection and order allocation under uncertainty in agile supply chains. In: IEEE International Conference on Emerging Technologies and Factory Automation, ETFA, IEEE, pp 1-6. https://doi.org/10.1109/ETFA.2015.7301509

Dursun M (2017) A fuzzy MCDM framework based on fuzzy measure and fuzzy integral for agile supplier evaluation. In: AIP Conference Proceedings, vol 1836. AIP, 020066. https://doi.org/10.1063/1.4982006

El Mokadem M (2017) The classification of supplier selection criteria with respect to lean or agile manufacturing strategies. J Manuf Technol Manag 28(2):232-249. https://doi.org/10.1108/JMTM-042016-0050

Freeman J, Chen T (2015) Green supplier selection using an AHP-Entropy-TOPSIS framework. Supply Chain Manag 20(3):327-340. https://doi.org/10.1108/SCM-04-2014-0142

Galankashi MR, Hisjam M, Helmi SA (2016) Agile supplier selection: A fuzzy analytic hierarchy process (FAHP) approach. In: Proceedings of the International Conference on Industrial Engineering and Operations Management, IEOM, pp. 1033-1040.

Gerwin D (1993) Manufacturing flexibility. A strategic perspective. Manag Sci 39(4):395-410. https://doi.org/10.1287/mnsc.39.4.395

Ghobakhloo M (2020) Industry 4.0, digitization, and opportunities for sustainability. J Clean Prod 252(2020):119869. https://doi.org/10.1016/j.jclepro.2019.119869

Ghoushchi SJ, Yousefi S, Khazaeili M (2019) An extended FMEA approach based on the Z-MOORA and fuzzy BWM for prioritization of failures. Appl Soft Comput 81:105505. https://doi.org/10.1016/j.asoc.2019.105505

Green KW, Zelbst PJ, Meacham J, Bhadauria VS (2012) Green supply chain management practices: Impact on performance. Supply Chain Manag 17(3):290-305. https://doi.org/10.1108/13598541211227126

Gunasekaran A (1999) Agile manufacturing: a framework for research and development. Int J Prod Econ 62(1-2):87-105. https://doi.org/10.1016/S0925-5273(98)00222-9

Guo S, Zhao H (2017) Fuzzy best-worst multi-criteria decision-making method and its applications. KnowlBased Syst 121:23-31. https://doi.org/10.1016/j.knosys.2017.01.010

Guo Z, Liu H, Zhang D, Yang J (2017) Green supplier evaluation and selection in apparel manufacturing using a fuzzy multi-criteria decision-making approach. Sustainability 9(4):650. https://doi.org/10.3390/su9040650

Gupta S, Soni U, Kumar G (2019) Green supplier selection using multi-criterion decision making under fuzzy environment: A case study in automotive industry. Comput Ind Eng 136:663-680. https://doi.org/10.1016/j.cie.2019.07.038

Haeri SAS, Rezaei J (2019) A grey-based green supplier selection model for uncertain environments. J Clean Prod 221:768-784. https://doi.org/10.1016/j.jclepro.2019.02.193

Handfield R, Walton SV, Sroufe R, Melnyk SA (2002) Applying environmental criteria to supplier assessment: A study in the application of the Analytical Hierarchy Process. Eur J Oper Res 141(1):70-87. https://doi.org/10.1016/S0377-2217(01)00261-2 
Hasan MM, Jiang D, Ullah AS, Noor-E-Alam M (2020) Resilient supplier selection in logistics 4.0 with heterogeneous information. Expert Syst Appl 139:112799. https://doi.org/10.1016/j.eswa.2019.07.016

Hashemi SH, Karimi A, Tavana M (2015) An integrated green supplier selection approach with analytic network process and improved Grey relational analysis. Int J Prod Econ 159:178-191. https://doi.org/10.1016/j.ijpe.2014.09.027

Hermann M, Pentek T, Otto B (2016) Design principles for industrie 4.0 scenarios. In: Proceedings of the Annual Hawaii International Conference on System Sciences (HICSS), IEEE, pp 3928-3937. https://doi.org/10.1109/HICSS.2016.488

Ighravwe DE, Oke SA (2019) An integrated approach of SWARA and fuzzy COPRAS for maintenance technicians' selection factors ranking. Int J Syst Assur Eng Manag 10(6):1615-1626. https://doi.org/10.1007/s13198-019-00912-8

Ijadi Maghsoodi A, Mosavat M, Hafezalkotob A, Hafezalkotob A (2019) Hybrid hierarchical fuzzy group decision-making based on information axioms and BWM: Prototype design selection. Comput Ind Eng 127:788-804. https://doi.org/10.1016/j.cie.2018.11.018

Jayant A, Agarwal A (2019) A novel hybrid MCDM approach based on DEMATEL, AHP and TOPSIS to evaluate green suppliers. In: Journal of Physics: Conference Series, IOP Publishing, 1240(1). https://doi.org/10.1088/1742-6596/1240/1/012010

Jiang P, Hu YC, Yen GF, Tsao SJ (2018) Green supplier selection for sustainable development of the automotive industry using grey decision-making. Sustain Dev 26(6):890-903. https://doi.org/10.1002/sd.1860

Kamble SS, Gunasekaran A, Gawankar SA (2018) Sustainable Industry 4.0 framework: A systematic literature review identifying the current trends and future perspectives. Process Saf Environ Prot 117:408425. https://doi.org/10.1016/j.psep.2018.05.009

Kannan D, Govindan K, Rajendran S (2015) Fuzzy axiomatic design approach based green supplier selection: A case study from Singapore. J Clean Prod 96:194-208. https://doi.org/10.1016/j.jclepro.2013.12.076

Karimi H, Sadeghi-Dastaki M, Javan M (2020) A fully fuzzy best-worst multi attribute decision making method with triangular fuzzy number: A case study of maintenance assessment in the hospitals. Appl Soft Comput 86:105882. https://doi.org/10.1016/j.asoc.2019.105882

Keršulienė V, Zavadskas EK, Turskis Z (2010) Selection of rational dispute resolution method by applying new step-wise weight assessment ratio analysis (SWARA). J Bus Econ Manag 11(2):243-258. https://doi.org/10.3846/jbem.2010.12

Keshavarz Ghorabaee M, Zavadskas EK, Amiri M, Esmaeili A (2016) Multi-criteria evaluation of green suppliers using an extended WASPAS method with interval type-2 fuzzy sets. J Clean Prod 137:213-229. https://doi.org/10.1016/j.jclepro.2016.07.031

Keshavarz Ghorabaee M, Amiri M, Zavadskas EK, Antucheviciene J (2018) A new hybrid fuzzy MCDM approach for evaluation of construction equipment with sustainability considerations. Arch Civ Mech Eng 18(1):32-49. https://doi.org/10.1016/j.acme.2017.04.011

Kumar P, Singh RK, Vaish A (2017) Suppliers' green performance evaluation using fuzzy extended ELECTRE approach. Clean Technol Environ Policy 19(3):809-821. https://doi.org/10.1007/s10098-016-1268-y

Kumar M, Garg D, Agarwal A (2019) Fuzzy DEMATEL approach for agile supplier selections performance criteria. In: Journal of Physics: Conference Series, IOP Publishing, 1240(1). https://doi.org/10.1088/1742$6596 / 1240 / 1 / 012157$

Kuo TC, Hsu CW, Li JY (2015) Developing a green supplier selection model by using the DANP with VIKOR. Sustainability 7(2): 1661-1689. https://doi.org/10.3390/su7021661 
Lee J, Cho H, Kim YS (2015) Assessing business impacts of agility criterion and order allocation strategy in multi-criteria supplier selection. Expert Syst Appl 42(3):1136-1148. https://doi.org/10.1016/j.eswa.2014.08.041

Li JQ, Wang JD, Pan QK, Duan PY, Sang HY, Gao KZ, Xue Y (2017) A hybrid artificial bee colony for optimizing a reverse logistics network system. Soft Comput 21(20):6001-6018. https://doi.org/10.1007/s00500-0172539-1

Liang R, Chong HY (2019) A hybrid group decision model for green supplier selection: a case study of megaprojects. Eng Constr Archit Manag 26(8):1712-1734. https://doi.org/10.1108/ECAM-10-2018-0462

Lichtblau K, Stich V, Bertenrath R, Blum M, Bleider M, Millack A, Schmitt K, Schmitz E, Schröter M (2014) Impuls - Industrie 4.0 Readiness. Impuls-Stiftung Des VDMA.

Lin KP, Hung KC, Lin YT, Hsieh YH (2017) Green suppliers performance evaluation in belt and road using fuzzy weighted average with social media information. Sustainability 10(1):1-11. https://doi.org/10.3390/su10010005

Lu Y (2017) Industry 4.0: A survey on technologies, applications and open research issues. J Ind Inf Integr 6:1-10. https://doi.org/10.1016/j.jii.2017.04.005

Lu Z, Sun X, Wang Y, Xu C (2019) Green supplier selection in straw biomass industry based on cloud model and possibility degree. J Clean Prod 209:995-1005. https://doi.org/10.1016/j.jclepro.2018.10.130

Luo X, Wu C, Rosenberg D, Barnes D (2009) Supplier selection in agile supply chains: An informationprocessing model and an illustration. J Purch Supply Manag 15(4):249-262. https://doi.org/10.1016/j.pursup.2009.05.004

Mahdiraji HA, Arzaghi S, Stauskis G, Zavadskas EK (2018) A hybrid fuzzy BWM-COPRAS method for analyzing key factors of sustainable architecture. Sustainability 10(1626):1-26. https://doi.org/10.3390/su10051626

Mangan J, Lalwani C (2016) Global logistics and supply chain management. 3rd ed. John Wiley \& Sons, USA.

Matawale CR, Datta S, Mahapatra SS (2016) Supplier selection in agile supply chain: Application potential of FMLMCDM approach in comparison with Fuzzy-TOPSIS and Fuzzy-MOORA. Benchmarking 23(7):20272060. https://doi.org/10.1108/BIJ-07-2015-0067

Mavi RK, Goh M, Zarbakhshnia N (2017) Sustainable third-party reverse logistic provider selection with fuzzy SWARA and fuzzy MOORA in plastic industry. Int J Adv Manuf Technol 91(5):2401-2418. https://doi.org/10.1007/s00170-016-9880-x

Momen S, Tavakkoli-Moghaddam R, Ghasemkhani A, Shahnejat-Bushehri S, Tavakkoli-Moghaddam H (2019) Prioritizing surgical cancellation factors based on a fuzzy best-worst method: A case study. IFACPapersOnLine 52(13):112-117. https://doi.org/10.1016/j.ifacol.2019.11.161

Moslem S, Gul M, Farooq D, Celik E, Ghorbanzadeh O, Blaschke T (2020) An integrated approach of bestworst method (bwm) and triangular fuzzy sets for evaluating driver behavior factors related to road safety. Mathematics 8(3):414. https://doi.org/10.3390/math8030414

Mousakhani S, Nazari-Shirkouhi S, Bozorgi-Amiri A (2017) A novel interval type-2 fuzzy evaluation model based group decision analysis for green supplier selection problems: A case study of battery industry. J Clean Prod 168:205-218. https://doi.org/10.1016/j.jclepro.2017.08.154

Omrani H, Alizadeh A, Emrouznejad A (2018) Finding the optimal combination of power plants alternatives: A multi response Taguchi-neural network using TOPSIS and fuzzy best-worst method. J Clean Prod 203:210223. https://doi.org/10.1016/j.jclepro.2018.08.238

Özbek A, Yildiz A (2020) Digital supplier selection for a garment business using interval type-2 fuzzy TOPSIS. Tekst Konfeksiyon, 30(1):61-72. https://doi.org/10.32710/tekstilvekonfeksiyon.569884 
Özkaya A, Gür Ş, Eren T (2019) Endüstri 4.0’a geçiş sürecinin Analitik Ağ Süreci ile değerlendirilmesi. Başkent Üniversitesi Ticari Bilimler Fakültesi Dergisi, 3(2):59-74.

Perçin S (2019) An integrated fuzzy SWARA and fuzzy AD approach for outsourcing provider selection. J Manuf Technol Manag 30(2):531-552. https://doi.org/10.1108/JMTM-08-2018-0247

Prater E, Biehl M, Smith MA (2001) International supply chain agility Tradeoffs between flexibility and uncertainty. Int J Oper Prod Manag 21(5-6):823-839. https://doi.org/10.1108/01443570110390507

Quan MY, Wang ZL, Liu HC, Shi H (2018) A Hybrid MCDM Approach for Large Group Green Supplier Selection with Uncertain Linguistic Information. IEEE Access 6: 50372-50383. https://doi.org/10.1109/ACCESS.2018.2868374

Ren R, Liao H, Al-Barakati A, Cavallaro F (2019) Electric vehicle charging station site selection by an integrated hesitant fuzzy swara-waspas method. Transform Bus Econ 18(2):103-123.

Rezaei J (2015) Best-worst multi-criteria decision-making method. Omega 53:49-57. https://doi.org/10.1016/j.omega.2014.11.009

Rezaei J (2016) Best-worst multi-criteria decision-making method: Some properties and a linear model. Omega 64:126-130. https://doi.org/10.1016/j.omega.2015.12.001

Roblek V, Meško M, Krapež A (2016) A Complex View of Industry 4.0. SAGE Open 6(2):1-11. https://doi.org/10.1177/2158244016653987

Rüßmann M, Lorenz M, Gerbert P, Waldner M, Justus J, Engel P, Harnisch M (2015) Industry 4.0: The Future of Productivity and Growth in Manufacturing Industries. Boston Consulting.

Sachdeva N, Shrivastava AK, Chauhan A (2019) Modeling supplier selection in the era of Industry 4.0. Benchmarking. https://doi.org/10.1108/BIJ-12-2018-0441

Sahu AK, Sahu NK, Sahu AK (2016) Application of integrated TOPSIS in ASC index: partners benchmarking perspective. Benchmarking, 23(3):540-563. https://doi.org/10.1108/BIJ-03-2014-0021

Salam MA (2019) Analyzing manufacturing strategies and Industry 4.0 supplier performance relationships from a resource-based perspective. Benchmarking: An International Journal. https://doi.org/10.1108/BIJ12-2018-0428

Salimi N, Rezaei J (2018) Evaluating firms' R D performance using best worst method. Eval Program Plann 66:147-155. https://doi.org/10.1016/j.evalprogplan.2017.10.002

Schuh G, Anderl R, Gausemeier J, ten Hompel M, Wahlster W (2017) Industrie 4.0 Maturity Index. Acatech Study.

Schumacher A, Erol S, Sihn W (2016) A Maturity Model for Assessing Industry 4.0 Readiness and Maturity of Manufacturing Enterprises. Procedia CIRP 52:161-166. https://doi.org/10.1016/j.procir.2016.07.040

Shariari M, Pilevari N (2016) Agile Supplier Selection In Sanitation Supply Chain Using Fuzzy VIKOR Method. J Op Ind Eng 10(21):19-28. https://doi.org/10.22094/JOIE.2016.257

Sharma M, Joshi S (2020) Digital supplier selection reinforcing supply chain quality management systems to enhance firm's performance. TQM Journal. https://doi.org/10.1108/TQM-07-2020-0160

Shaw S, Grant DB, Mangan J (2010) Developing environmental supply chain performance measures. In Benchmarking: An International Journal 17(3):320-339. https://doi.org/10.1108/14635771011049326

Sivaprakasam R, Selladurai V, Sasikumar P (2015) Integrating environmental factors in the suppliers assessment using analytic hierarchy process as a decision making tool. J Mater Environ Sci 6(8):2097-2104.

Srivastava SK (2007) Green supply-chain management: A state-of-the-art literature review. Int J Manag Rev 9(1):53-80. https://doi.org/10.1111/j.1468-2370.2007.00202.x 
Stanujkic D, Karabasevic D, Zavadskas EK (2015) A framework for the selection of a packaging design based on the SWARA method. Eng Econ 26(2):181-187. https://doi.org/10.5755/j01.ee.26.2.8820

Sumrit D (2020) Supplier selection for vendor-managed inventory in healthcare using fuzzy multi-criteria decision-making approach. Decis Sci Lett 9(2):233-256. https://doi.org/10.5267/j.dsl.2019.10.002

Tian ZP, Wang JQ, Zhang HY (2018) An integrated approach for failure mode and effects analysis based on fuzzy best-worst, relative entropy, and VIKOR methods. Appl Soft Comput 72:636-646. https://doi.org/10.1016/j.asoc.2018.03.037

Topaloglu M, Yarkin F, Kaya T (2018) Solid waste collection system selection for smart cities based on a type-2 fuzzy multi-criteria decision technique. Soft Comput 22(15):4879-4890. https://doi.org/10.1007/s00500-018-3232-8

Torkayesh SE , Iranizad A, Torkayesh AE, Basit MN (2020) Application of BWM-WASPAS model for digital supplier selection problem: A case study in online retail shopping. J Ind Eng Decis Mak 1(1):12-23. https://doi.org/10.31181/jiedm200101012t

Ulrich D, Yeung A (2019) Agility: the new response to dynamic change. Strategic HR Review 18(4):161-167. https://doi.org/10.1108/shr-04-2019-0032

Uygun Ö, Dede A (2016) Performance evaluation of green supply chain management using integrated fuzzy multi-criteria decision making techniques. Comput Ind Eng 102:502-511. https://doi.org/10.1016/j.cie.2016.02.020

van de Kaa G, Janssen M, Rezaei J (2018) Standards battles for business-to-government data exchange: Identifying success factors for standard dominance using the Best Worst Method. Technol Forecast Soc Change 137:182-189. https://doi.org/10.1016/j.techfore.2018.07.041

Wan S, Lin LL, Dong JY (2017) MAGDM based on triangular Atanassov's intuitionistic fuzzy information aggregation. Neural Comput Appl 28(9):2687-2702. https://doi.org/10.1007/s00521-016-2196-9

Wang Chen HM, Chou SY, Luu QD, Yu THK (2016) A Fuzzy MCDM Approach for Green Supplier Selection from the Economic and Environmental Aspects. Math Probl Eng 2016. https://doi.org/10.1155/2016/8097386

Weyer S, Schmitt M, Ohmer, M, Gorecky D (2015) Towards industry 4.0 - Standardization as the crucial challenge for highly modular, multi-vendor production systems. IFAC-PapersOnLine 48(3):579-584. https://doi.org/10.1016/j.ifacol.2015.06.143

Wu C, Barnes D (2009) A model for continuous improvement in supplier selection in agile supply chains. Knowl Process Manag 16(3):85-110. https://doi.org/10.1002/kpm.327

Wu C, Barnes D, Rosenberg D, Luo X (2009) An analytic network process-mixed integer multi-objective programming model for partner selection in agile supply chains. Prod Plan Control 20(3):254-275. https://doi.org/10.1080/09537280902856047

Yadollahi S, Kazemi A, Ranjbarian B (2018) Identifying and prioritizing the factors of service experience in banks: A best-Worst method. Decis Sci Lett 7(4):455-464. https://doi.org/10.5267/j.dsl.2018.1.002

Yazdani M, Chatterjee P, Zavadskas EK, Hashemkhani Zolfani S (2017) Integrated QFD-MCDM framework for green supplier selection. J Clean Prod 142:3728-3740. https://doi.org/10.1016/j.jclepro.2016.10.095

Zarbakhshnia N, Soleimani H, Ghaderi H (2018) Sustainable third-party reverse logistics provider evaluation and selection using fuzzy SWARA and developed fuzzy COPRAS in the presence of risk criteria. Appl Soft Comput 65:307-319. https://doi.org/10.1016/j.asoc.2018.01.023

Zavadskas EK, Stevic Ž, Tanackov I, Prentkovskis O (2018) A novel multicriteria approach - rough step-wise weight assessment ratio analysis method (R-SWARA) and its application in logistics. Stud Inform Control, 27(1):97-106. https://doi.org/10.24846/v27i1y201810 
Zhou J, Yu T, Zhang Y, Chi J, Li X, Wang W (2008) Study on partner selection of the agile supply chain based on fuzzy analytic hierarchy process. In: Proceedings of the IEEE International Conference on Automation and Logistics, ICAL 2008, IEEE, pp 1362-1365. https://doi.org/10.1109/ICAL.2008.4636365

Zhu Q, Sarkis J, Lai KH (2008) Confirmation of a measurement model for green supply chain management practices implementation. Int J Prod Econ 111(2):261-273. https://doi.org/10.1016/j.ijpe.2006.11.029

Zolfani SH, Chatterjee P (2019) Comparative evaluation of sustainable design based on Step-WiseWeight Assessment Ratio Analysis (SWARA) and Best Worst Method (BWM) methods: A perspective on household furnishing materials. Symmetry 11(1):74. https://doi.org/10.3390/sym11010074

\section{Appendices}

Table 15. Calculation of weights of dimensions based on DM evaluations

\begin{tabular}{|c|c|c|c|c|c|c|}
\hline $\begin{array}{l}\mathrm{DM}_{1} \\
\text { order }\end{array}$ & $D_{n}$ & Variable & $\mathrm{S}_{\mathrm{j}}$ & $\mathrm{k}_{\mathrm{j}}$ & $\mathrm{q}_{j}$ & $\mathrm{w}_{\mathrm{j}}$ \\
\hline 1 & $\mathrm{D}_{2}$ & - & - & $(1,1,1)$ & $(1,1,1)$ & $\begin{array}{c}(0.4405,0.4615 \\
0.4929)\end{array}$ \\
\hline 2 & $\mathrm{D}_{1}$ & LI & $\begin{array}{c}(2 / 5,1 / 2, \\
2 / 3)\end{array}$ & $(7 / 5,3 / 2,5 / 3)$ & $\begin{array}{c}(0.6000,0.6667 \\
0.7142)\end{array}$ & $\begin{array}{c}(0.2643,0.3077 \\
0.3521)\end{array}$ \\
\hline 3 & $\mathrm{D}_{3}$ & VI & $\begin{array}{c}2 / 7,1 / 3 \\
2 / 5)\end{array}$ & $(9 / 7,4 / 3,7 / 5)$ & $\begin{array}{c}(0.4285,0.5000 \\
0.5556)\end{array}$ & $\begin{array}{c}(0.1888,0.2307 \\
0.2738)\end{array}$ \\
\hline $\begin{array}{l}\mathrm{DM}_{2} \\
\text { order }\end{array}$ & $\overline{D_{n}}$ & Variable & $\mathrm{S}_{\mathrm{j}}$ & $\mathrm{k}_{\mathrm{j}}$ & $\mathrm{q}_{\mathrm{j}}$ & $\mathrm{w}_{\mathrm{j}}$ \\
\hline 1 & $\mathrm{D}_{2}$ & - & - & $(1,1,1)$ & $(1,1,1)$ & $\begin{array}{c}(0.5102,0.5714 \\
0.6410)\end{array}$ \\
\hline 2 & $\mathrm{D}_{3}$ & MI & $(2 / 3,1,3 / 2)$ & $(5 / 3,2,5 / 2)$ & $\begin{array}{c}(0.4000,0.5000 \\
0.6000)\end{array}$ & $\begin{array}{c}(0.2040,0.2857 \\
0.3846)\end{array}$ \\
\hline 3 & $\mathrm{D}_{1}$ & MI & $(2 / 3,1,3 / 2)$ & $(5 / 3,2,5 / 2)$ & $\begin{array}{c}(0.1600,0.2500 \\
0.3600)\end{array}$ & $\begin{array}{c}(0.0816,0.1428 \\
0.2307)\end{array}$ \\
\hline $\begin{array}{l}\mathrm{DM}_{3} \\
\text { order }\end{array}$ & $\mathrm{D}_{\mathrm{n}}$ & Variable & $\mathrm{Sj}_{\mathrm{j}}$ & $\mathrm{k}_{\mathrm{j}}$ & $q_{j}$ & $\mathrm{w}_{\mathrm{j}}$ \\
\hline 1 & $\mathrm{D}_{3}$ & - & - & $(1,1,1)$ & $(1,1,1)$ & $\begin{array}{c}(0.4162,0.4285 \\
0.4455)\end{array}$ \\
\hline 2 & $\mathrm{D}_{1}$ & ML & $\begin{array}{c}(2 / 9,1 / 4 \\
2 / 7)\end{array}$ & $(11 / 9,5 / 4,9 / 7)$ & $\begin{array}{c}(0.7778,0.8000 \\
0.8181)\end{array}$ & $\begin{array}{c}(0.3237,0.3428 \\
0.3645)\end{array}$ \\
\hline 3 & $\mathrm{D}_{2}$ & LI & $\begin{array}{c}(2 / 5,1 / 2 \\
2 / 3)\end{array}$ & $(7 / 5,3 / 2,5 / 3)$ & $\begin{array}{c}(0.4666,0.5334 \\
0.5844)\end{array}$ & $\begin{array}{c}(0.1942,0.2285 \\
0.2603)\end{array}$ \\
\hline
\end{tabular}

Table 16. Calculation of the weights of green dimension criteria according to $\mathrm{DM}_{1}$ 's evaluations

\begin{tabular}{|c|c|c|c|c|c|c|}
\hline Order & $\mathrm{C}_{1 \mathrm{n}}$ & Variable & $\mathrm{S}_{\mathrm{j}}$ & $\mathrm{k}_{\mathrm{j}}$ & $\mathrm{q}_{\mathrm{j}}$ & $\mathrm{wj}$ \\
\hline 1 & $\mathrm{C}_{15}$ & - & - & $(1,1,1)$ & $(1,1,1)$ & $(0.3211,0.3627,0.4183)$ \\
\hline 2 & $\mathrm{C}_{14}$ & $\mathrm{LI}$ & $(2 / 5,1 / 2$, & $(7 / 5,3 / 2$, & $(0.6000,0.6667$, & $(0.1927,0.2418,0.2988)$ \\
& & & $2 / 3)$ & $5 / 3)$ & $0.7142)$ & \\
\hline 3 & $\mathrm{C}_{11}$ & $\mathrm{LI}$ & $(2 / 5,1 / 2$, & $(7 / 5,3 / 2$, & $(0.3600,0.4444$, & $(0.1156,0.1612,0.2134)$ \\
& & & $2 / 3)$ & $5 / 3)$ & $0.5102)$ & \\
\hline 4 & $\mathrm{C}_{12}$ & VI & $(2 / 7,1 / 3$, & $(9 / 7,4 / 3$, & $(0.2571,0.3333$, & $(0.0826,0.1209,0.1660)$ \\
& & & $2 / 5)$ & $7 / 5)$ & $0.3968)$ & \\
\hline
\end{tabular}




\begin{tabular}{|c|c|c|c|c|c|c|}
\hline 5 & $\overline{\mathrm{C}_{13}}$ & MI & $(2 / 3,1,3 / 2)$ & $(5 / 3,2,5 / 2)$ & $\begin{array}{c}(0.1028,0.1667 \\
0.2381)\end{array}$ & $(0.0330,0.0604,0.0996)$ \\
\hline 6 & $\mathrm{C}_{17}$ & MI & $(2 / 3,1,3 / 2)$ & $(5 / 3,2,5 / 2)$ & $\begin{array}{c}(0.0411,0.0833 \\
0.1428)\end{array}$ & $(0.0132,0.0302,0.0597)$ \\
\hline 7 & $\mathrm{C}_{16}$ & VI & $\begin{array}{c}(2 / 7,1 / 3 \\
2 / 5)\end{array}$ & $\begin{array}{c}(9 / 7,4 / 3 \\
7 / 5)\end{array}$ & $\begin{array}{c}(0.0293,0.0625 \\
0.1111)\end{array}$ & $(0.0094,0.0226,0.0464)$ \\
\hline
\end{tabular}

Table 17. The best and worst alternatives against the criteria according to DM's evaluations

\begin{tabular}{|c|c|c|c|c|c|c|c|c|}
\hline \multicolumn{3}{|c|}{$\mathrm{DM}_{1}$} & \multicolumn{3}{|c|}{$\mathrm{DM}_{2}$} & \multicolumn{3}{|c|}{$\mathrm{DM}_{3}$} \\
\hline Criteria & Best & Worst & Criteria & Best & Worst & Criteria & Best & Worst \\
\hline $\mathrm{C}_{11}$ & $\mathrm{~A}_{2}$ & $\mathrm{~A}_{4}$ & $\mathrm{C}_{11}$ & $\mathrm{~A}_{2}$ & $\mathrm{~A}_{1}$ & $\mathrm{C}_{11}$ & $\mathrm{~A}_{2}$ & $\mathrm{~A}_{4}$ \\
\hline $\mathrm{C}_{12}$ & $\mathrm{~A}_{3}$ & $\mathrm{~A}_{4}$ & $\mathrm{C}_{12}$ & $\mathrm{~A}_{2}$ & $\mathrm{~A}_{1}$ & $\mathrm{C}_{12}$ & $\mathrm{~A}_{2}$ & $\mathrm{~A}_{4}$ \\
\hline $\mathrm{C}_{13}$ & $\mathrm{~A}_{3}$ & $\mathrm{~A}_{4}$ & $\mathrm{C}_{13}$ & $\mathrm{~A}_{3}$ & $\mathrm{~A}_{4}$ & $\mathrm{C}_{13}$ & $\mathrm{~A}_{2}$ & $\mathrm{~A}_{1}$ \\
\hline $\mathrm{C}_{14}$ & $\mathrm{~A}_{2}$ & $A_{1}$ & $\mathrm{C}_{14}$ & $\mathrm{~A}_{2}$ & $\mathrm{~A}_{4}$ & $\mathrm{C}_{14}$ & $\mathrm{~A}_{3}$ & $\mathrm{~A}_{1}$ \\
\hline $\mathrm{C}_{15}$ & $\mathrm{~A}_{2}$ & $\mathrm{~A}_{4}$ & $\mathrm{C}_{15}$ & $\mathrm{~A}_{3}$ & $\mathrm{~A}_{4}$ & $\mathrm{C}_{15}$ & $A_{2}$ & $\mathrm{~A}_{1}$ \\
\hline $\mathrm{C}_{16}$ & $A_{1}$ & $\mathrm{~A}_{3}$ & $\mathrm{C}_{16}$ & $\mathrm{~A}_{3}$ & $\mathrm{~A}_{2}$ & $\mathrm{C}_{16}$ & $\mathrm{~A}_{2}$ & $\mathrm{~A}_{4}$ \\
\hline $\mathrm{C}_{17}$ & $\mathrm{~A}_{3}$ & $A_{1}$ & $\mathrm{C}_{17}$ & $\mathrm{~A}_{3}$ & $\mathrm{~A}_{1}$ & $\mathrm{C}_{17}$ & $A_{3}$ & $\mathrm{~A}_{4}$ \\
\hline $\mathrm{C}_{21}$ & $\mathrm{~A}_{4}$ & $A_{2}$ & $\mathrm{C}_{21}$ & $A_{1}$ & $\mathrm{~A}_{4}$ & $\mathrm{C}_{21}$ & $\mathrm{~A}_{4}$ & $\mathrm{~A}_{2}$ \\
\hline $\mathrm{C}_{22}$ & $A_{1}$ & $\mathrm{~A}_{3}$ & $\mathrm{C}_{22}$ & $\mathrm{~A}_{4}$ & $\mathrm{~A}_{2}$ & $\mathrm{C}_{22}$ & $\mathrm{~A}_{1}$ & $\mathrm{~A}_{3}$ \\
\hline $\mathrm{C}_{23}$ & $A_{1}$ & $A_{3}$ & $\mathrm{C}_{23}$ & $A_{1}$ & $\mathrm{~A}_{3}$ & $\mathrm{C}_{23}$ & $\mathrm{~A}_{1}$ & $\mathrm{~A}_{3}$ \\
\hline $\mathrm{C}_{24}$ & $\mathrm{~A}_{4}$ & $\mathrm{~A}_{2}$ & $\mathrm{C}_{24}$ & $A_{1}$ & $\mathrm{~A}_{2}$ & $\mathrm{C}_{24}$ & $A_{1}$ & $\mathrm{~A}_{2}$ \\
\hline $\mathrm{C}_{25}$ & $\mathrm{~A}_{4}$ & $A_{3}$ & $\mathrm{C}_{25}$ & $A_{1}$ & $\mathrm{~A}_{2}$ & $\mathrm{C}_{25}$ & $A_{1}$ & $\mathrm{~A}_{2}$ \\
\hline $\mathrm{C}_{26}$ & $\mathrm{~A}_{4}$ & $\mathrm{~A}_{3}$ & $\mathrm{C}_{26}$ & $\mathrm{~A}_{4}$ & $\mathrm{~A}_{3}$ & $\mathrm{C}_{26}$ & $\mathrm{~A}_{2}$ & $\mathrm{~A}_{3}$ \\
\hline $\mathrm{C}_{27}$ & $\mathrm{~A}_{4}$ & $\mathrm{~A}_{2}$ & $\mathrm{C}_{27}$ & $\mathrm{~A}_{1}$ & $\mathrm{~A}_{3}$ & $\mathrm{C}_{27}$ & $\mathrm{~A}_{2}$ & $\mathrm{~A}_{4}$ \\
\hline $\mathrm{C}_{31}$ & $\mathrm{~A}_{3}$ & $\mathrm{~A}_{1}$ & $\mathrm{C}_{31}$ & $\mathrm{~A}_{2}$ & $\mathrm{~A}_{1}$ & $\mathrm{C}_{31}$ & $\mathrm{~A}_{4}$ & $\mathrm{~A}_{1}$ \\
\hline $\mathrm{C}_{32}$ & $\mathrm{~A}_{2}$ & $\mathrm{~A}_{1}$ & $\mathrm{C}_{32}$ & $\mathrm{~A}_{2}$ & $\mathrm{~A}_{1}$ & $\mathrm{C}_{32}$ & $\mathrm{~A}_{2}$ & $\mathrm{~A}_{4}$ \\
\hline $\mathrm{C}_{33}$ & $\mathrm{~A}_{3}$ & $\mathrm{~A}_{1}$ & $\mathrm{C}_{33}$ & $\mathrm{~A}_{3}$ & $\mathrm{~A}_{4}$ & $\mathrm{C}_{33}$ & $\mathrm{~A}_{2}$ & $\mathrm{~A}_{3}$ \\
\hline $\mathrm{C}_{34}$ & $\mathrm{~A}_{3}$ & $\mathrm{~A}_{2}$ & $\mathrm{C}_{34}$ & $\mathrm{~A}_{2}$ & $\mathrm{~A}_{4}$ & $\mathrm{C}_{34}$ & $\mathrm{~A}_{3}$ & $\mathrm{~A}_{1}$ \\
\hline $\mathrm{C}_{35}$ & $\mathrm{~A}_{2}$ & $\mathrm{~A}_{1}$ & $\mathrm{C}_{35}$ & $\mathrm{~A}_{3}$ & $\mathrm{~A}_{4}$ & $\mathrm{C}_{35}$ & $\mathrm{~A}_{2}$ & $\mathrm{~A}_{4}$ \\
\hline $\mathrm{C}_{36}$ & $\mathrm{~A}_{4}$ & $\mathrm{~A}_{1}$ & $\mathrm{C}_{36}$ & $\mathrm{~A}_{4}$ & $A_{1}$ & $\mathrm{C}_{36}$ & $\mathrm{~A}_{3}$ & $\mathrm{~A}_{4}$ \\
\hline $\mathrm{C}_{37}$ & $\mathrm{~A}_{3}$ & $\mathrm{~A}_{1}$ & $\mathrm{C}_{37}$ & $\mathrm{~A}_{3}$ & $\mathrm{~A}_{4}$ & $\mathrm{C}_{37}$ & $A_{2}$ & $\mathrm{~A}_{1}$ \\
\hline
\end{tabular}

Table 18. Linguistic evaluations in $\mathrm{BO}$ and $\mathrm{OW}$ vector created against $\mathrm{C}_{12}$

\begin{tabular}{|c|c|c|c|c|}
\hline & Alternatives/DM & DM $_{1}$ & $\mathrm{DM}_{2}$ & $\mathrm{DM}_{3}$ \\
\hline \multirow{3}{*}{$\begin{array}{c}\text { BO } \\
\text { vector }\end{array}$} & $\mathrm{A}_{1}$ & FIM & VIM & VIM \\
\cline { 2 - 5 } & $\mathrm{A}_{2}$ & VIM & EIM & EIM \\
\cline { 2 - 5 } & $\mathrm{A}_{3}$ & EIM & FIM & VIM \\
\cline { 2 - 5 } & $\mathrm{A}_{4}$ & AIM & VIM & AIM \\
\hline \multirow{3}{*}{$\begin{array}{c}\text { OW } \\
\text { vector }\end{array}$} & $\mathrm{A}_{1}$ & FIM & EIM & VIM \\
\cline { 2 - 5 } & $\mathrm{A}_{2}$ & FIM & VIM & AIM \\
\cline { 2 - 5 } & $\mathrm{A}_{3}$ & AIM & FIM & FIM \\
\cline { 2 - 5 } & $\mathrm{A}_{4}$ & EIM & FIM & EIM \\
\hline
\end{tabular}


Table 19. Determining crisp number equivalents in $\mathrm{BO}$ and $\mathrm{OW}$ vectors created against $\mathrm{C}_{12}$

\begin{tabular}{|c|c|c|c|c|c|c|c|}
\hline & & \multicolumn{2}{|c|}{ DM $_{1}$} & \multicolumn{2}{c|}{$\mathrm{DM}_{2}$} & \multicolumn{2}{c|}{$\mathrm{DM}_{3}$} \\
\hline \multirow{5}{*}{ B0 } & & $\begin{array}{c}\text { Fuzzy } \\
\text { number }\end{array}$ & $\begin{array}{c}\text { Crisp } \\
\text { number }\end{array}$ & $\begin{array}{c}\text { Fuzzy } \\
\text { number }\end{array}$ & $\begin{array}{c}\text { Crisp } \\
\text { number }\end{array}$ & $\begin{array}{c}\text { Fuzzy } \\
\text { number }\end{array}$ & $\begin{array}{c}\text { Crisp } \\
\text { number }\end{array}$ \\
\hline \multirow{5}{*}{ OW } & $\mathrm{A}_{1}$ & $(3 / 2,2,5 / 2)$ & 2 & $(5 / 2,3,7 / 2)$ & 3 & $(5 / 2,3,7 / 2)$ & 3 \\
\cline { 2 - 8 } & $\mathrm{A}_{2}$ & $(5 / 2,3,7 / 2)$ & 3 & $(1,1,1)$ & 1 & $(1,1,1)$ & 1 \\
\cline { 2 - 8 } & $\mathrm{A}_{3}$ & $(1,1,1)$ & 1 & $(3 / 2,2,5 / 2)$ & 2 & $(5 / 2,3,7 / 2)$ & 3 \\
\cline { 2 - 8 } & $\mathrm{A}_{4}$ & $(7 / 2,4,9 / 2)$ & 4 & $(5 / 2,3,7 / 2)$ & 3 & $(7 / 2,4,9 / 2)$ & 4 \\
\hline \multirow{5}{*}{} & $\mathrm{A}_{1}$ & $(3 / 2,2,5 / 2)$ & 2 & $(1,1,1)$ & 1 & $(5 / 2,3,7 / 2)$ & 3 \\
\cline { 2 - 8 } & $\mathrm{A}_{2}$ & $(3 / 2,2,5 / 2)$ & 2 & $(5 / 2,3,7 / 2)$ & 3 & $(7 / 2,4,9 / 2)$ & 4 \\
\cline { 2 - 8 } & $\mathrm{A}_{3}$ & $(7 / 2,4,9 / 2)$ & 4 & $(3 / 2,2,5 / 2)$ & 2 & $(3 / 2,2,5 / 2)$ & 2 \\
\cline { 2 - 8 } & $\mathrm{A}_{4}$ & $(1,1,1)$ & 1 & $(3 / 2,2,5 / 2)$ & 2 & $(1,1,1)$ & 1 \\
\hline
\end{tabular}


Table 20. Evaluation results of alternatives, $\xi^{*}$ values and consistency ratios according to each DM

\begin{tabular}{|c|c|c|c|c|c|c|c|c|c|c|c|c|c|c|c|c|c|c|}
\hline \multicolumn{7}{|c|}{$\mathrm{DM}_{1}$} & \multicolumn{6}{|c|}{$\mathrm{DM}_{2}$} & \multicolumn{6}{|c|}{$\mathrm{DM}_{3}$} \\
\hline $\mathrm{C}_{\mathrm{nn}}$ & $\mathrm{A}_{1}$ & $\mathrm{~A}_{2}$ & $\mathrm{~A}_{3}$ & $\mathrm{~A}_{4}$ & $\xi^{*}$ & $\xi^{*} / \mathrm{CI}=\mathrm{CR}$ & $\mathrm{A}_{1}$ & $\mathrm{~A}_{2}$ & $\mathrm{~A}_{3}$ & $\mathrm{~A}_{4}$ & $\xi^{*}$ & $\overline{C R}$ & $\overline{A_{1}}$ & $\mathrm{~A}_{2}$ & $\mathrm{~A}_{3}$ & $\mathrm{~A}_{4}$ & $\xi^{*}$ & $\overline{C R}$ \\
\hline $\mathrm{C}_{11}$ & 0.2483 & 0.4379 & 0.1897 & 0.1241 & 0.0586 & 0.0073 & 0.1269 & 0.3654 & 0.3013 & 0.2064 & 0.0474 & 0.0071 & 0.1805 & 0.4774 & 0.2068 & 0.1353 & 0.0639 & 0.0079 \\
\hline $\mathrm{C}_{12}$ & 0.2553 & 0.1702 & 0.4681 & 0.1064 & 0.0426 & 0.0053 & 0.1235 & 0.4444 & 0.2593 & 0.1728 & 0.0741 & 0.0111 & 0.2000 & 0.5000 & 0.2000 & 0.1000 & 0.1000 & 0.0124 \\
\hline $\mathrm{C}_{13}$ & 0.2000 & 0.2000 & 0.5000 & 0.1000 & 0.1000 & 0.0124 & 2553 & 0.1702 & 0.4681 & .1064 & 0.0426 & 0.0053 & 0952 & 0.4286 & 0.2381 & 0.2381 & 0.0476 & 0.0059 \\
\hline $\mathrm{C}_{14}$ & 0.1525 & 0.3635 & 0.2552 & 0.2288 & 0.0942 & 0.0141 & 2381 & 0.4286 & 2381 & 0.0952 & 0.0476 & 0.0059 & 1241 & 0.2483 & 0.4759 & 0.1517 & 0.0207 & 0.0026 \\
\hline $\mathrm{C}_{15}$ & 0.3273 & 0.3727 & 0.2000 & 0.1000 & 0.0273 & 0.0034 & 0.1805 & 0.2707 & 0.4135 & 1353 & 0.1278 & 0.0159 & 1032 & 0.3809 & 0.2302 & 0.2857 & 0.0794 & 0.0099 \\
\hline $\mathrm{C}_{16}$ & 0.3809 & 0.2302 & 0.1032 & 0.2857 & 0.0794 & 0.0099 & 0.3003 & 0.0957 & 0.4258 & 0.1782 & 0.1089 & 0.0135 & 0.2483 & 0.4379 & 0.1897 & 0.1241 & 0.0586 & 0.0073 \\
\hline $\mathrm{C}_{17}$ & 0.1000 & 0.2000 & 0.5000 & 0.2000 & 0.1000 & 0.0124 & 0.1111 & 0.2909 & 0.3758 & 0.2222 & 0.0687 & 0.0085 & 0.1805 & 0.2707 & 0.4135 & 0.1353 & 0.1278 & 0.0159 \\
\hline $\mathrm{C}_{21}$ & 0.2288 & 0.1525 & 0.2552 & 0.3635 & 0.0942 & 0.0141 & 0.3758 & 0.2909 & 0.2222 & 0.1111 & 0.0687 & 0.0085 & 0.2031 & 0.1016 & 0.3849 & 0.3104 & 0.0959 & 0.0119 \\
\hline $\mathrm{C}_{22}$ & 0.3541 & 0.2486 & 1486 & 0.2486 & 0.0917 & 0.0137 & 0.2018 & 0.1579 & 0.2018 & 0.4386 & 0.0351 & 0.0052 & 0.3815 & 0.3146 & 0.0884 & 0.2155 & 0.0495 & 0.0062 \\
\hline $\mathrm{C}_{23}$ & 0.3635 & 0.2552 & .1525 & 0.2288 & 0.0942 & 0.0141 & 0.3541 & 0.2486 & 0.1486 & 0.2486 & 0.0917 & 0.0137 & .3703 & 0.1603 & 0.1050 & 0.3644 & 0.0496 & 0.0062 \\
\hline $\mathrm{C}_{24}$ & 0.2581 & 0.1098 & 1870 & 4451 & 0.0711 & 0.0088 & 3793 & 0.1241 & 0.2483 & 0.2483 & 0.1172 & 0.0146 & 0.4286 & 0.0952 & 0.2381 & 0.2381 & 0.0476 & 0.0059 \\
\hline $\mathrm{C}_{25}$ & 0.2909 & 0.2222 & 0.1111 & 0.3758 & 0.0687 & 0.0085 & 0.5000 & 0.1000 & 0.2000 & 0.2000 & 0.1000 & 0.0124 & 0.3104 & 0.1016 & 0.3849 & 0.2031 & 0.0959 & 0.0119 \\
\hline $\mathrm{C}_{26}$ & 0.2727 & 0.1818 & 0.0909 & 0.4545 & 0.0909 & 0.0113 & 0.2483 & 0.2483 & 0.1241 & 0.3793 & 0.1172 & 0.0146 & 0.2044 & 0.4972 & 0.0994 & 0.1989 & 0.0994 & 0.0124 \\
\hline $\mathrm{C}_{27}$ & 0.3408 & 0.0942 & 0.2466 & 0.3185 & 0.0582 & 0.0072 & 0.4297 & 0.1927 & 0.1406 & 0.2370 & 0.0443 & 0.0066 & 0.2483 & 0.3793 & 0.2483 & 0.1241 & 0.1172 & 0.0146 \\
\hline $\mathrm{C}_{31}$ & 0.1111 & 0.2222 & 0.3758 & 0.2909 & 0.0687 & 0.0085 & 0.0884 & 0.3815 & 0.2155 & 0.3146 & .0495 & 0.0062 & 0.1111 & 0.2222 & 0.2222 & 0.4444 & 0.0000 & 0.0000 \\
\hline $\mathrm{C}_{32}$ & 0.0833 & 0.4167 & 0.3333 & 0.1667 & 0.0833 & 0.0104 & 0.0957 & 0.4258 & 0.3003 & 0.1782 & 0.1089 & 0.0135 & 0.1833 & 0.3688 & 0.3118 & 0.1361 & 0.0396 & 0.0059 \\
\hline $\mathrm{C}_{33}$ & 0.1303 & 0.2180 & 0.3106 & 0.3411 & 0.0804 & 0.0120 & 0.2616 & 0.1628 & 0.4709 & 0.1047 & 0.0523 & 0.0065 & 0.2553 & 0.4681 & 0.1064 & 0.1702 & 0.0426 & 0.0053 \\
\hline $\mathrm{C}_{34}$ & 0.1818 & 0.0909 & 0.4545 & 0.2727 & 0.0909 & 0.0113 & 0.2258 & 0.4194 & 0.2258 & 0.1290 & 0.0323 & 0.0048 & 0.1111 & 0.2909 & 0.3758 & 0.2222 & 0.0687 & 0.0085 \\
\hline $\mathrm{C}_{35}$ & 0.1000 & 0.3727 & 0.3273 & 0.2000 & 0.0273 & 0.0034 & 0.2000 & 0.2000 & 0.5000 & 0.1000 & 0.1000 & 0.0124 & 0.2581 & 0.4451 & 0.1870 & 0.1098 & 0.0711 & 0.0088 \\
\hline $\mathrm{C}_{36}$ & 0.1579 & 0.2018 & 0.2018 & 0.4386 & 0.0351 & 0.0052 & 0.1000 & 0.2000 & 0.2000 & 0.5000 & 0.1000 & 0.0124 & 0.2483 & 0.2483 & 0.3793 & 0.1241 & 0.1172 & 0.0146 \\
\hline $\mathrm{C}_{37}$ & 0.1406 & 0.1927 & 0.4297 & 0.2370 & 0.0443 & 0.0066 & 0.2857 & 0.2302 & 0.3809 & 0.1032 & 0.0794 & 0.0099 & 0.1032 & 0.3809 & 0.2302 & 0.2857 & 0.0794 & 0.0099 \\
\hline
\end{tabular}


